\section{Mechanisms of biogenic gas migration revealed by seep carbonate paragenesis, Panoche Hills, California}

\section{Jean-Philippe Blouet, Patrice Imbert, and Anneleen Foubert}

\section{ABSTRACT}

A comprehensive study of seep carbonates at the top of the organic-rich Maastrichtian to Danian Moreno Formation in the Panoche Hills (California) reveals the mechanisms of generation, expulsion, and migration of biogenic methane that fed the seeps. Two selected outcrops show that seep carbonates developed at the tip of sand dykes intrude up into the Moreno Formation from deeper sandbodies. Precipitation of methane-derived cements occurred in a succession of up to 10 repeated elementary sequences, each starting with a corrosion surface followed by dendritic carbonates, botryoidal aragonite, aragonite fans, and finally laminated micrite. Each element of the sequence reflects three stages. First, a sudden methane pulse extended up into the oxic zone of the sediments, leading to aerobic oxidation of methane and carbonate dissolution. Second, after consumption of the oxygen, anaerobic oxidation of methane coupled with sulfate reduction triggered carbonate precipitation. Third, progressive diminishment of the methane seepage led to the deepening of the reaction front in the sediment and the lowering of precipitation rates. Carbonate isotopes, with $\delta^{13} \mathrm{C}$ as low as $-51 \%$ Peedee belemnite, indicate a biogenic origin for the methane, whereas a one-dimensional basin model suggests that the Moreno Formation was in optimal thermal conditions for bacterial methane generation at the time of seep carbonate precipitation. Methane pulses are interpreted to reflect drainage by successive episodes of sand injection into the gas-generating shale of the Moreno Formation. The seep carbonates of the Panoche Hills can thus be viewed as a record of methane production from a biogenic source rock by multiphase hydraulic fracturing.

Copyright (C2017. The American Association of Petroleum Geologists. All rights reserved. Gold Open Access. This paper is published under the terms of the CC-BY license.

Manuscript received February 16, 2016; provisional acceptance April 21, 2016; revised manuscript received August 5, 2016; final acceptance October 17, 2016.

DOI:10.1306/10171616021

\section{AUTHORS}

JEAN-PhILIPPE Blouet Department of Geosciences, University of Fribourg, Chemin du Musée 6, 1700 Fribourg, Switzerland; jean-philippe.blouet@unifr.ch

Jean-Philippe Blouet is a research geoscientist with more than 10 years of experience in carbonate concretions. He has a double M.Sc. degree in petroleum geology awarded from the University of Nancy (France). He worked at Total's headquarters from 2012 to 2014 . He is currently researching the petroleum significance of seep carbonates in an industryfunded Ph.D. project with Total at the University of Fribourg (Switzerland).

PATRICE IMBERT Centre Scientifique et Technique Jean Féger, Total, Avenue Larribau, 64000 Pau, France; patrice. imbert@total.com

Patrice Imbert, Ph.D., is a geologist at Total Exploration and Production, Research and Development division. He specialized first in turbidite sedimentology and seismic interpretation in Total's headquarters and occupied various positions overseas in exploration and reservoir geology. His current research interests are fluid flow in sedimentary basins, with a special focus on the seismic expression of hydrocarbon migration and expulsion, present and past.

ANNELEEN FouberT $\sim$ Department of Geosciences, University of Fribourg, Chemin du Musée 6, 1700 Fribourg, Switzerland; anneleen.foubert@unifr.ch

Anneleen Foubert has been an associate professor of carbonate sedimentology at the University of Fribourg (Switzerland) since February 2013. Previously, she worked as researcher at the University of Leuven (Belgium) and as carbonate sedimentologist at Total (Pau, France). Trained as a marine geologist at Ghent University (Belgium), she specializes in the study of carbonate mound systems through space and time.

\section{ACKNOWLEDGMENTS}

We thank Total Exploration and Production for the financing of Jean-Philippe Blouet, for granting permission to publish this research, 
and for many insightful discussions, in particular with geoscientists of the sedimentology and geochemistry research teams. The field campaign in 2013 was greatly facilitated by Ivano Aiello, who granted access to the Moss Landing Marine Laboratories, and Hilde Schwartz is acknowledged for providing access to the library of the University of Santa Cruz. Both Hilde and Ivano greatly helped to guide the early field reconnaissance. Sutieng $\mathrm{Ho}$ is greatly thanked for assisting the completion of this manuscript and for her useful advice and stimulating discussions of the work. We thank Kristin and Everett Meagher Robinson for their warm welcome in California. We are grateful to Giovanni Aloisi, who offered fruitful insights into the subject in its early stages. Thin Section Lab and its personnel are thanked for providing access to their facilities. We are grateful to Robin Fentimen for his correction of the English language. Reviews of the original manuscript by Martin Hovland and an anonymous reviewer were constructive and beneficial.

\section{EDITOR'S NOTE}

Color versions of Figures 1-15 and Tables 1-2 can be seen in the online version of this paper.

\section{INTRODUCTION}

Seep carbonates result from hydrocarbon migration up to the seabed at sites called cold seeps (Paull et al., 1984; Boetius and Wenzhöfer, 2013). They precipitate during the biocatalyzed anaerobic oxidation of methane (AOM) and by sulfate reduction in the sulfate-methane transition zone (SMTZ; Boetius et al., 2000). The first direct observations of seep carbonates precipitating on the sea floor originated from Hovland et al. (1985) and Ritger et al. (1987). Later, Roberts (2001) demonstrated that seep carbonate facies were controlled by the hydrocarbon flux dynamics and by the depth of the SMTZ in the sediment (Roberts, 2001). Regnier et al. (2011) showed that seep carbonates could precipitate at the seabed if the methane flux were sufficient to exceed the rate of sulfate diffusion into the sediment or within the subseafloor at diffusion rates. Paull and Ussler (2008) also reported that migrating gas could shift the SMTZ upward and precipitate a greater amount of carbonate. Furthermore, the abundance of carbonate decreases and carbonate depth below seabed increases away from the venting site. In particular, where the SMTZ is close to the seabed, it can support the establishment of a chemosynthesis-based megafauna (Gay et al., 2006; Judd and Hovland, 2007) dominated by mollusks, annelids, and crustaceans (Kiel, 2010). Gas seepage intensity varies over various time scales (Naudts et al., 2010; Ho et al., 2012) as a function of migration mechanisms and pathways, typically faults, hydrofractures, or sand injectites (Mazzini et al., 2003; Duranti and Mazzini, 2005; Jonk et al., 2005; Hurst and Cartwright, 2007; Ho et al., 2016). The Panoche giant injection complex (California) is one of the world's largest sand injection complexes. It is an ensemble of intrusive sedimentary features produced by elevation of pore pressure in a sand reservoir leading to hydrofracturation of a sealing strata, fluidization, and injection of the sand slurry (Hurst et al., 2011). The Panoche giant injection complex developed from the sandy turbidites of the Upper Cretaceous Panoche Formation through the overlying Maastrichtian to Danian low porosity Moreno Formation along a vertical section of $1200 \mathrm{~m}$ $(0.75 \mathrm{mi})$ and over at least $300 \mathrm{~km}^{2}\left(115 \mathrm{mi}^{2}\right)$. The Panoche giant injection complex has been extensively studied by many authors (Vigorito et al., 2008; Vétel and Cartwright, 2010; Vigorito and Hurst, 2010; Scott et al., 2013). Schwartz et al. (2003) and Minisini and Schwartz (2007) described seep carbonates at the top of the Moreno Formation. The authors correlated seep carbonate distributions over several kilometers to the presence of underlying sand dykes emanating from the Panoche Formation, thereby providing evidence that the injectites served as hydrocarbon migration pathways. However, the source rock was not identified, and the migration mechanisms were not detailed in these publications. In general terms, although seep carbonates are 
obvious hydrocarbon indicators, examples of seep carbonates used as a tool to reconstruct a complete petroleum system still remain scarce. A petroleum system, as defined by Magoon and Dow (1994), is the concept unifying the essential elements of petroleum geology (source rock, reservoir, seal, overburden), processes (generation, migration, accumulation), and that includes shows and seeps.

Based on detailed study of two outcrops in the Panoche Hills, identification of a recurrent paragenetic sequence, and distribution of a chemosynthetic fossil fauna, this study evaluates the paleofluid flux. It also addresses the issue of hydrocarbon generation using one-dimensional (1-D) thermal modeling of the organic-rich Moreno Formation and its potential as a biogenic source rock. By combining an assessment of the seepage style at the sea floor and the fracturing mechanisms of the source rock at depth, this paper proposes a comprehensive model for the generation, expulsion, and migration processes of methane in the Panoche Hills during the earliest Paleocene.

\section{GEOLOGICAL SETTING}

The Panoche Hills are located in the Coast Range along the western edge of the San Joaquin Valley in central California, approximately $200 \mathrm{~km}$ (125 mi) southeast of San Francisco. The San Joaquin Valley constitutes the southern part of the Great Valley, a northwest-southeast elongated basin, $700 \mathrm{~km}$ (435 mi) long and $100 \mathrm{~km}$ (62 mi) wide (Figure 1).

\section{Geodynamic Context}

From the Late Jurassic to the Oligocene, the Great Valley was a forearc basin, located between the Sierra Nevada magmatic arc to the west and the Franciscan subduction complex to the east (Dickinson and Seely, 1979; Ingersoll, 2008). It is filled with up to $9 \mathrm{~km}$ (6 mi) of sediment, mostly composed of shale and turbidite (Bailey et al., 1964; Bartow and Nilsen, 1990). During the Neogene, tectonic plate motion switched from convergent to strike slip, leading to the emplacement of the San Andreas Fault and associated uplift of the western side of the Great Valley (Atwater and Molnar, 1973; Graham et al., 1984; Norris and Webb, 1990). As a consequence, the western edge of the Great Valley is at present tilted approximately $40^{\circ}$ toward the axis of the San Joaquin Valley, and a nearly complete sedimentary infill from the ophiolitic bedrock up to Oligocene strata is exposed (Figure 2).

\section{Stratigraphy}

The oldest exposed sedimentary rocks, in faulted contact with the Franciscan complex, belong to the Panoche Formation (Anderson and Pack, 1915). This 6.5-km (4-mi)-thick formation is dated Campanian to Maastrichtian and comprises conglomeratic sandstone in the lower part, transitioning upward to channelized turbiditic sandstone interbedded with shale. It corresponds to deep-sea fan deposits sourced from the eroded Sierra Nevada (Ingersoll, 1979; McGuire, 1988). The overlying Maastrichtian to Danian Moreno Formation is 450 to $650 \mathrm{~m}$ (1475 to $2130 \mathrm{ft}$ ) thick in the study area (Scott et al., 2013) and is composed of fine-grained units divided into five members: Dosados, Tierra Loma Shale, Marca Shale, Dos Palos Shale, and Cima Sandstone Lentil (Payne, 1951). The Dos Palos Shale Member contains the Cima Sandstone Lentil. The dominant lithology of the formation is clayey, with diatomite in the Marca Shale Member. The Cima Sandstone Lentil is silty to sandy. From the Dosados to the Marca Shale Members, laminated facies dominate, and benthic biotas are rare, thus indicating deposition in anoxic conditions, whereas suboxic conditions are suggested in the nonlaminated Dos Palos Shale Member (McGuire, 1988). Biostratigraphic analysis of the series by Martin (1964) showed a progressive overall shoaling throughout the Moreno Formation, which Martin (1964) interpreted as a transition from the base of slope to a shelfal environment.

Concretions interpreted as seep carbonates (Schwartz et al., 2003) are present in the Dos Palos Shale Member, up to the Cima Sandstone Lentil stratigraphic level (Minisini and Schwartz, 2007). However, they are isolated and rare in the Dos Palos Shale Member and are abundant only in the Cima Sandstone Lentil. Minisini and Schwartz (2007) distinguished three types of concretions based on their overall geometry. They defined (1) nodules as subspherical masses with diameters ranging from a few inches to several yards; (2) mounds as irregular, roughly conical bodies a few yards in diameter; and (3) crusts as stratiform bodies. 
Figure 1. Geodynamic setting of the Panoche Hills outcrop. (A) Location of the study area along the western margin of the North American continent. (B) Simplified geological map of California. (C) Schematic cross section of the western American plate during the early Paleocene. (D) Recent geological profile (modified from Dickinson and Seely, 1979, with permission of AAPG).
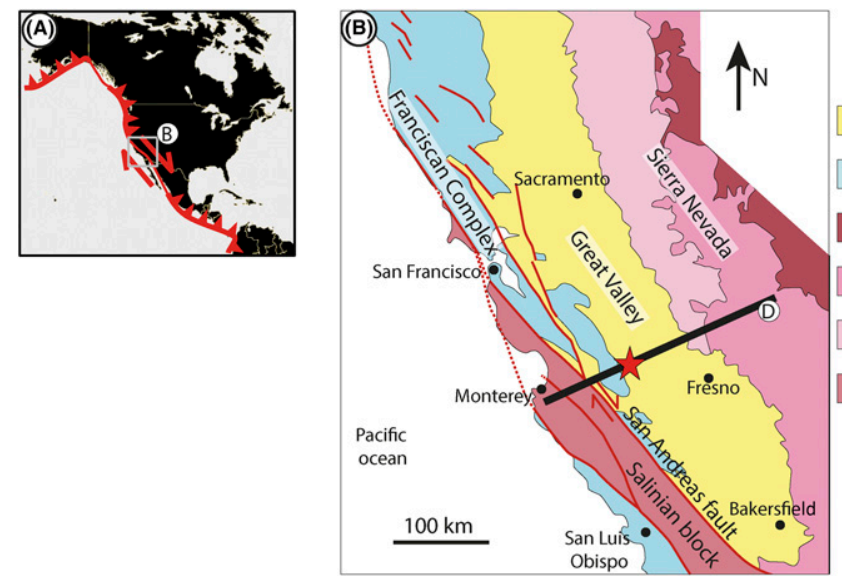

Mesozoic Great Valley rocks

Mesozoic Franciscan assemblage (sedimentary and ophiolitic rocks)

Cenozoic volcanic rocks

Sierra Nevada granitic rocks

Sierra Nevada metamorphic rocks

Salinian block metamorphic and granitic rocks

to Panoche Hills
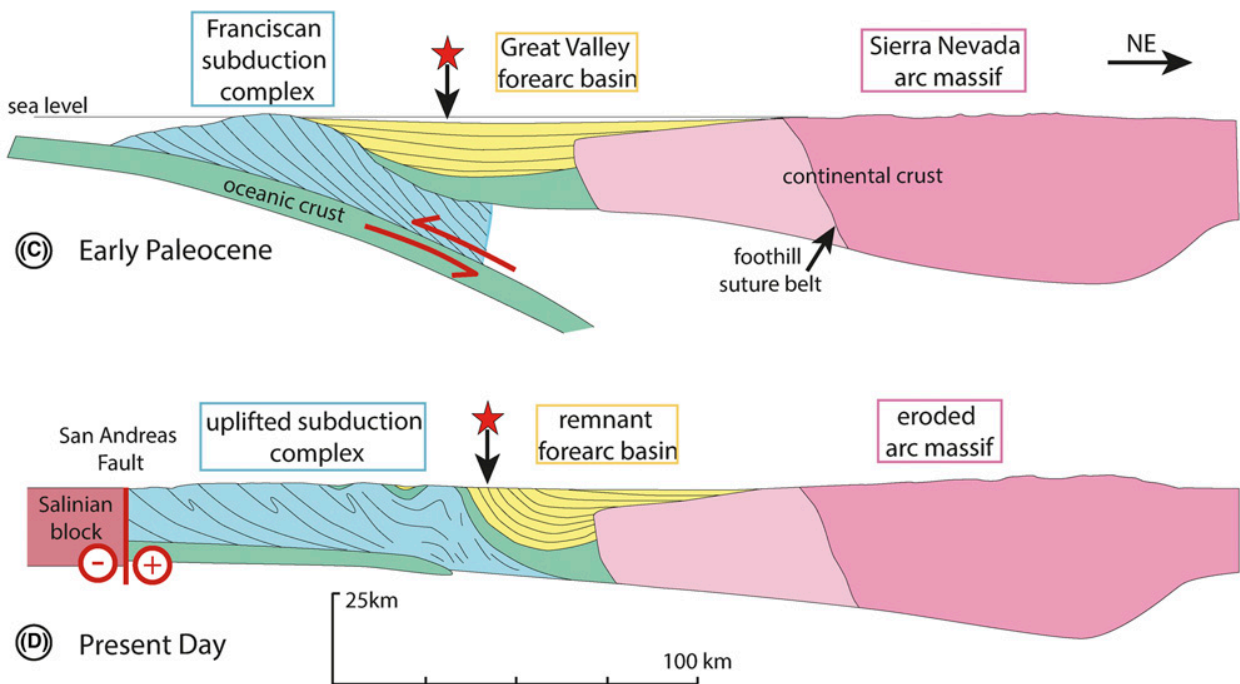

The Moreno Formation is unconformably overlain by Paleocene and Eocene marine deposits. During the Oligocene and Neogene, the northern part of the San Joaquin Valley was uplifted, resulting in deposition of continental to very shallow water deposits (Bartow, 1991).

\section{The Panoche Giant Injection Complex and Its Relation to Seepage}

Extensively studied over the past two decades (Hurst and Cartwright, 2007), the Panoche Hills host one of the best exposed sand injection complexes in the world. Sands, from the Panoche Formation, intruded more that $1 \mathrm{~km}(0.6 \mathrm{mi})$ upward (not decompacted) into the overlying low-permeability seal constituted by the Moreno Formation. Most injectites terminate below the Dos Palos Shale Member, with a few reaching the Cima Sandstone Lentil (Weberling,
2002; Scott et al., 2013). Based on sandstone grain composition and possible sand volcano morphologies, Vigorito et al. (2008) interpreted sandstone beds in the Cima Sandstone Lentil to be at least partially of extrusive origin. Therefore, sand extrusion onto the sea floor dates back to the Danian. The Panoche giant injection complex thus exposes all three genetic units involved in the sand remobilization systems: the sand reservoir unit, the intruded unit, and the extrusive unit (Figure 2).

Minisini and Schwartz (2007) conducted a statistical study of the densities of injectites and the density of overlying seep carbonates over a $20-\mathrm{km}$ (12-mi)-long outcrop, suggesting that the injectites acted as a hydrocarbon pathway up to the sea floor. The distribution of seep carbonates over a thick sedimentary column suggests that seepage and injectite emplacement spread over a substantial time interval before sand extrusion on the sea floor (Weberling, 2002). 


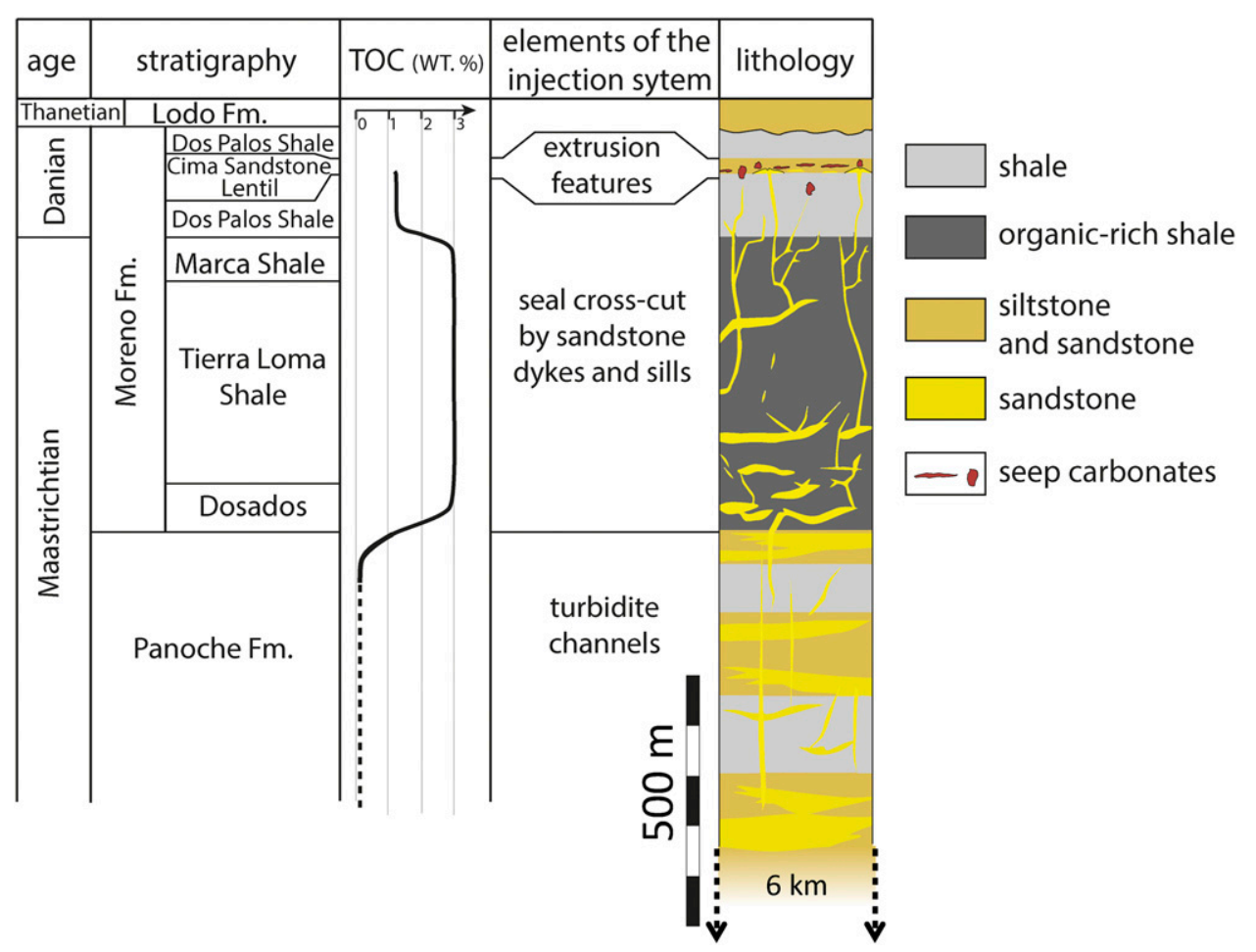

Figure 2. General stratigraphy and lithology of the Panoche Hills in the Escarpado-Right Angle Canyon area (after Scott et al., 2013, with permission of AAPG). Total organic carbon (TOC) curve from McGuire (1988) and He et al. (2014). Fm. = Formation.

\section{Source-Rock Properties}

The alternation of coarse turbidites and organic-poor shale of the Panoche Formation is not considered a source rock for potential hydrocarbons (He et al., 2014). In contrast, the Moreno Formation is the only known Cretaceous source rock in the region (McGuire, 1988; Peters et al., 2007). Peters et al. (2007) determined an original total organic carbon (TOC) value of the Moreno Formation as high as 3.7\% based on 326 samples from 11 wells. In particular, from well Exxon 1 Chounet Ranch, located $11 \mathrm{~km}$ $(7 \mathrm{mi})$ westward from the studied outcrop, McGuire (1988) reported an average TOC of 3\% for the laminated lower part of the Moreno Formation (i.e., the Dosados Member, the Tierra Loma Shale Member, and the Marca Shale Member) and $1.2 \%$ TOC for the Dos Palos Shale Member. Biomarker analyses by Bac (1990) on cores of Exxon 1 Chounet Ranch indicate a marine origin for the organic matter.

\section{MATERIALS AND METHODS}

Carbonate concretions, widespread in the Cima Sandstone Lentil, have been observed in detail along

a $4.5-\mathrm{km}$ (2.8-mi)-long, nearly continuous, outcrop in the central part of the Panoche Hills, from the Dosados Canyon to Panoche Creek (Figure 3). This paper distingushes the three types of concretions recognized by Minisini and Schwartz (2007) (nodule, mound, crust).

Polished slabs of rock were observed in natural light and 365-nm ultraviolet light (UV); 50 thin sections were examined with optical microscopy using plane-polarized light, cross-polarized light, and cathodoluminescence (CL). The CL was generated by a CITL system, model CCL 8200 ink $4(12 \mathrm{kV}, 450 \mathrm{~mA})$.

Scanning electron microscope (SEM) observations were carried out on fresh, fractured surfaces coated with gold and on thin sections coated with carbon. Energy dispersive spectrometry (EDS) was used to determine the qualitative elemental composition of carbon-coated samples.

For x-ray diffraction (XRD), 27 samples were crushed manually in an agate mortar. The powders were analyzed with a Rigaku Ultima IV diffractometer system equipped with a $\mathrm{Cu} \mathrm{x}$-ray tube, operated at $40 \mathrm{kV}$ and $40 \mathrm{~mA}$, and with a D-Tex linear detector. Scans were run from $5^{\circ}$ to $70^{\circ} 2 \theta$, with a step interval of $0.01^{\circ} 2 \theta$ and a goniometry speed of $120 \mathrm{~s} /{ }^{\circ} 2 \theta$. The identification of all minerals was performed 
Figure 3. Geological map of the southeastern Panoche Hills showing the locations of the studied outcrops (topographic map from the US Geological Survey, 1956). Fm. = Formation.

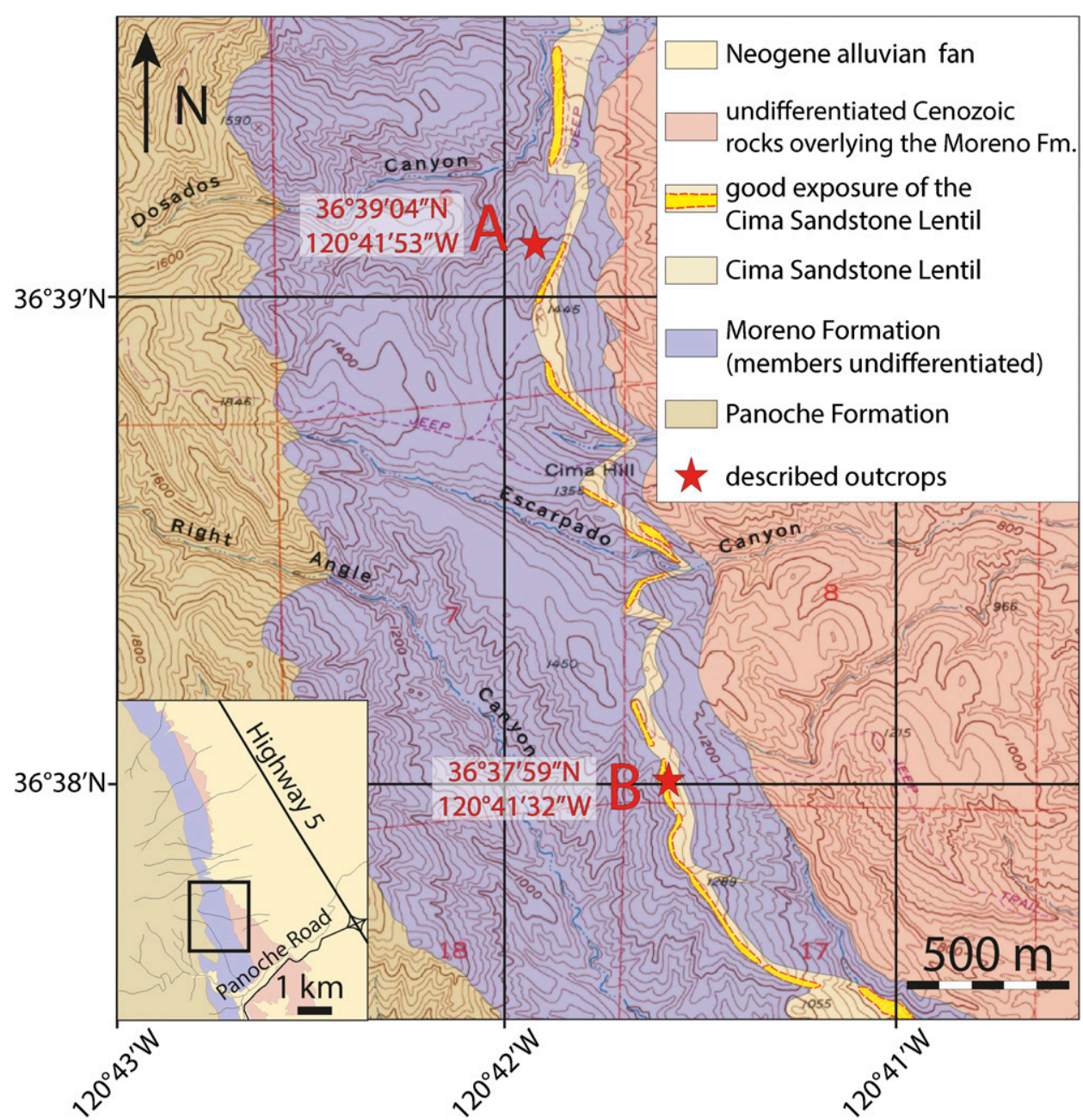

using the Rigaku PDXL2 software package and the ICDD Powder Diffraction File 2014 database (International Centre for Diffraction Data).

For stable oxygen and carbon isotope analysis, 78 samples of carbonate were selected. They were taken from polished blocks and on rock chips using a handheld microdrill under an alternation of natural and UV light. Samples were then analyzed using a Kiel III automated carbonate preparation device coupled to a Finnigan MAT 252 isotope-ratio mass spectrometer. Carbonate material reacts with $100 \%$ phosphoric acid for $10 \mathrm{~min}$ at $70^{\circ} \mathrm{C}$. The $\mathrm{CO}_{2}$ product is then passed through the isotope-ratio mass spectrometer for masses 44, 45, and 46 measurements alternately with the measurement of a calibrated reference $\mathrm{CO}_{2}$ gas. Instrumental precision is monitored by analysis of NBS 18, NBS 19, and in some instances LSVEC reference material. Precisions are $\pm 0.05 \%$ for carbon and $\pm 0.14 \%$ o for oxygen. Isotope results are given relative to the Peedee belemnite standard.

\section{RESULTS}

At least two major clusters of carbonate concretions were observed in direct connection with dykes (Figure 3 ), and these are the main focus of this paper. They are referred to as "outcrop A" and "outcrop B" hereafter.

\section{Description of Outcrops A and B}

Outcrop A is located in the Dos Palos Shale Member, several tens of yards below the Cima Sandstone Lentil (Figure 3). It consists of a sandstone dyke surrounded

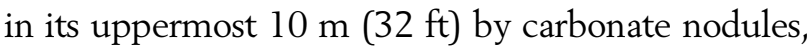
a few tens of centimeters in diameter. The dyke tip is 
capped by a 2-m (7-ft)-diameter mound (Figure 4A). Above outcrop A, The Cima Sandstone Lentil is poor in concretions and contains only a few nodules up to $1 \mathrm{~m}(3.2 \mathrm{ft})$ in diameter, crosscut by some thin dykes.

Outcrop B is located within the Cima Sandstone Lentil (Figure 3). It is composed of a cluster of five mounds $(\approx 1$ to $3 \mathrm{~m}$ [ 3 to $10 \mathrm{ft}$ ] in diameter) and many nodules overlying a dyke swarm (Figure 4B). Two sets of subvertical dykes, respectively oriented N070 and N140, are visible over several tens of meters. Four of the mounds occur at the same stratigraphic level, and one is located approximately $15 \mathrm{~m}(50 \mathrm{ft})$ below the others. Above the mounds, discontinuous stratiform concretions (crusts, oblate nodules) are widely distributed in this part of the Cima Sandstone Lentil.

\section{Authigenic Carbonates}

This section focuses on the mesoscopic characteristics of the carbonate concretions, whereas the petrography and geochemistry are analyzed in the Petrography of Carbonates and Stable Isotope Geochemistry sections, respectively.

\section{Mounds}

The mounds of outcrops A and B are characterized by a mottled carbonate fabric (Figure 5A) comprising lightgray patches of micrite in a brown to greenish microsparitic matrix. The boundary between the two colors ranges from smooth to sharp (Figure 5B, C). In places, brecciated pieces of the gray lithology are included in the brown one. The mounds are crosscut by randomly oriented septarian cracks up to $50 \mathrm{~cm}$ (20 in.) long.

Mounds differ from other carbonate concretions by the presence of numerous cylindrical tubes often coated by a cortex of light-gray carbonate, filled with several generations of cements (Figure 5C). The tubes are approximately $1.5 \mathrm{~cm}$ (0.6 in.) in diameter, randomly oriented and occasionally branched (Figure 5D). They are identified as cemented Thalassinoides burrows.

\section{Nodules}

The nodules, which are spatially associated with the mounds of outcrops $A$ and $B$, are smooth and subspherical reaching approximately $1 \mathrm{ft}(0.3 \mathrm{~m})$ in diameter. Nodules consist of gray to yellow micrite organized in concentric layers. The layers are continuous and isopachous in the central part of the nodules and commonly discontinuous in the external part (Figure 5E).

\section{Dykes}

\section{Geometry}

Two sets of dykes are present in outcrop B. The first consists of four subvertical dykes trending N140, and the other comprises approximately 10 subvertical dykes trending N70. The latter extend upward to the highest stratigraphic level, a few yards below the lowest mound. A dyke oriented N70 offsets one of the dykes oriented N140 (Figure 4), indicating that the second dyke set postdates the first. The maximum thickness observed for the dykes is approximately $30 \mathrm{~cm}$ (12 in.); their length ranges from a few meters to $150 \mathrm{~m}(500 \mathrm{ft})$. They are characterized by abundant en echelon segmentation (Figure 6A), a characteristic described as common in the area by Vétel and Cartwright (2010).

Outcrop A contains a single subvertical dyke trending N55. The thickness of the dyke decreases regularly from $20 \mathrm{~cm}$ (8 in.) at the bottom of the outcrop ( $\sim 20 \mathrm{~m}[65 \mathrm{ft}$ ] beneath the mound) to $2 \mathrm{~cm}$ (0.8 in.) $1 \mathrm{~m}$ [39 in.] below it. Dyke walls are smooth or locally covered by flute casts, with the tail pointing upward (Figure 6B), indicating an upward propagation of the sand slurry.

\section{Petrography}

Samples from dykes underlying concretions are composed of fine-grained quartzo-feldspathic sandstone $(<500 \mu \mathrm{m})$ cemented by equant calcite with undulating extinction and locally replaced by iron oxides (Figure 6C).

\section{Fauna}

Fossils in the Dos Palos Shale and Cima Sandstone Lentil are rare except for wood fragments commonly heavily perforated by xylophagous bivalves.

Bivalves, tube worms, and Thalassinoides are present in outcrop B (Figure 7A), whereas outcrop A only shows Thalassinoides. Thalassinoides are 

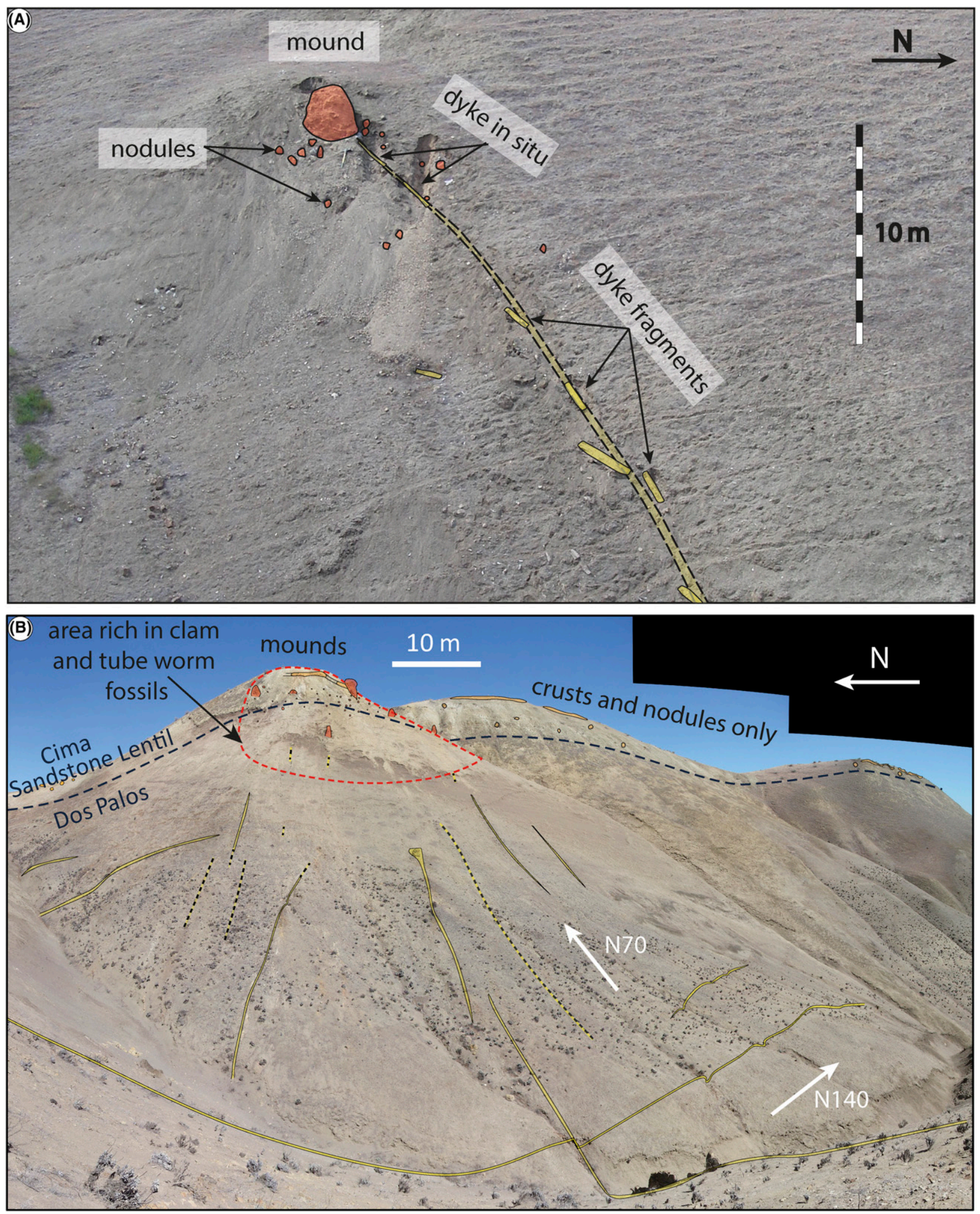

Figure 4. View of the two studied outcrops showing the relationship between dykes and overlying seep carbonates. Observed dykes are indicated by solid lines, whereas inferred dykes are represented as dotted lines. (A) Outcrop A. The upper part of the dyke is surrounded by nodules, and its tip is directly capped by a mound. The dyke is observed as fragments, and two excavations show it in situ. (B) Outrcop B: a cluster of mounds and nodules in the Cima Sandstone Lentil overlying a dyke swarm (directions of the dykes indicated by white arrows). Away from the dyke swarm, the concretions of the Cima Sandstone Lentil comprise only crusts and nodules. 

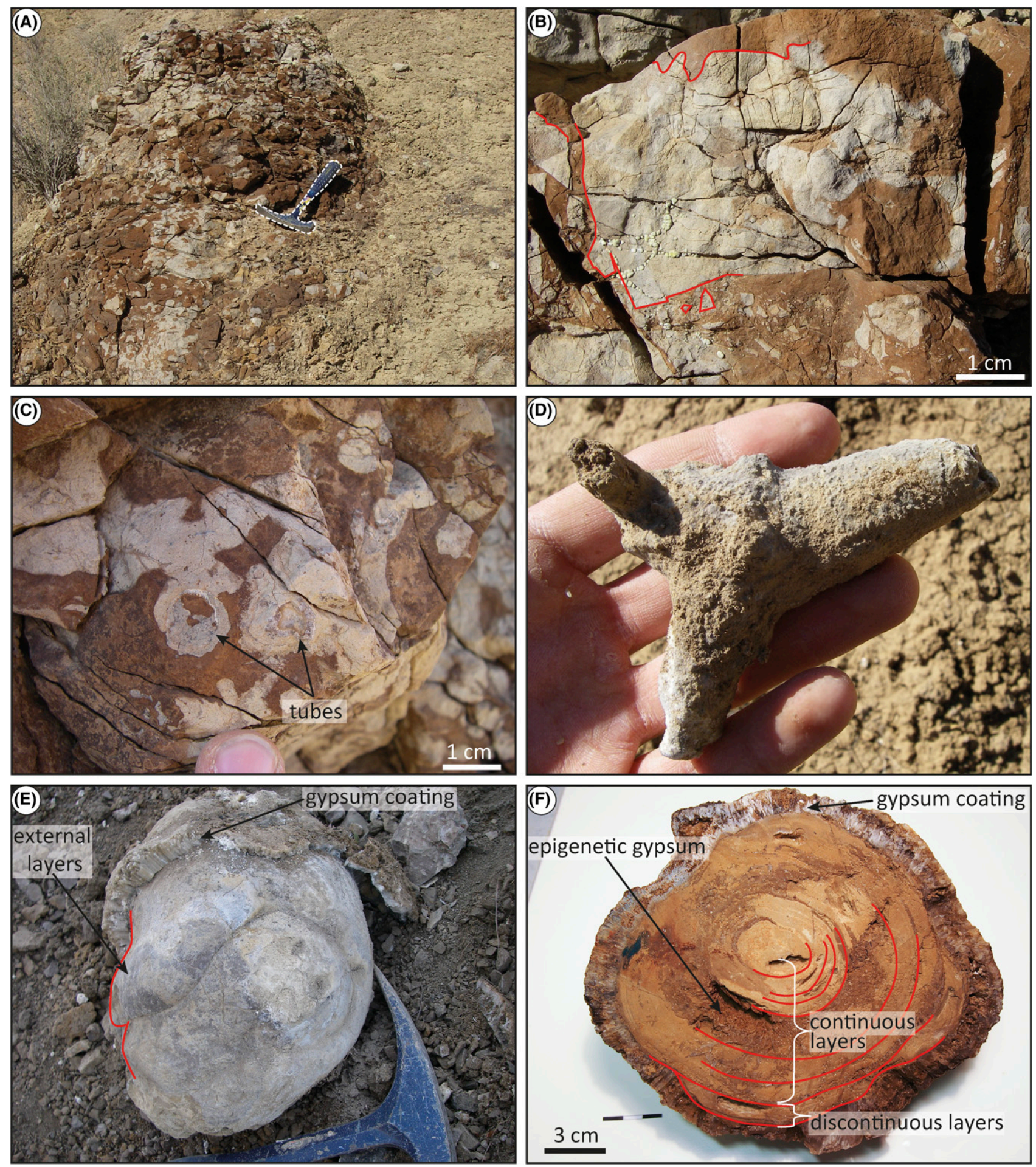

Figure 5. Macroscopic characteristics of mounds and nodules. (A) Typical structure of a mound, protruding from the sandy Cima Sandstone Lentil. The brown/gray mottled fabric is clearly visible. (B) Two types of contact between the gray micrite and the brown microsparite: brecciated (bottom of the picture) and smooth (top of the picture). (C) Two tubes filled with cements. They are hosted in a light-gray micrite surrounded by a brown microsparite. The contact between the gray and the brown matrices is smooth. (D) An isolated Thalassinoides burrow cemented by carbonate and gypsum. (E) A large nodule. The external layer is partially covering the inner layers. A neomorphosed crust of gypsum coats the nodule. (F) Cross section of a nodule. Concentric growth layers are visible, the inner layers are continuous and isopachous, whereas the external layer is discontinuous. This nodule is partially epigenized in gypsum. Note: A color version can be seen in the online version. 

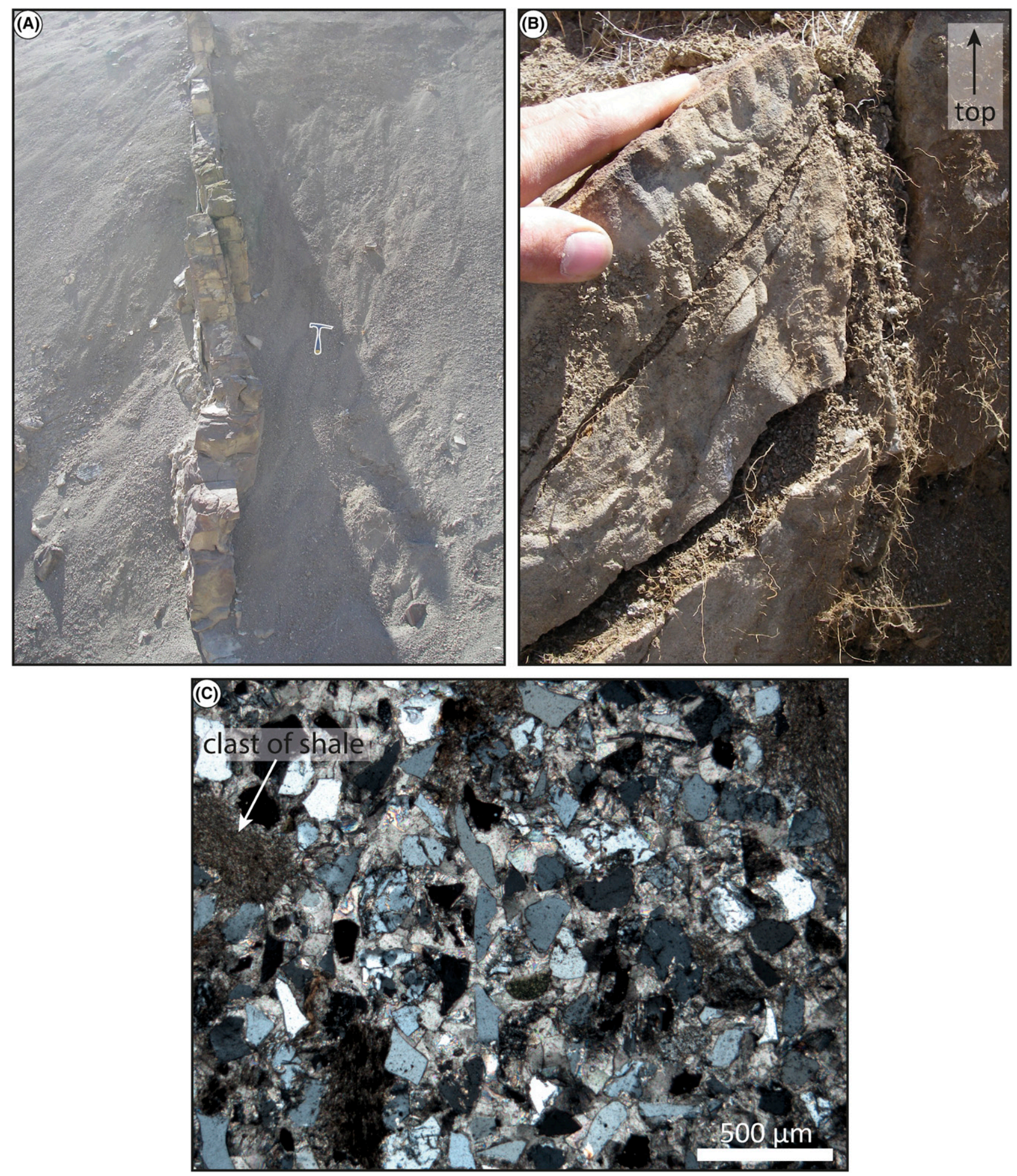

Figure 6. Dykes in the Moreno Formation. (A) A discontinuous dyke with overlapping segments (outcrop B). (B) Flute casts with tips orientated upward (outcrop A). (C) Thin section of sandstone dyke composed of quartz, feldspar, and some shale clasts cemented by calcite. 
common in mounds of the Panoche Hills but are rare within the shale or other types of concretions (crust and nodules).

In outcrop $B$, the distribution of fauna is strictly restricted to a roughly 50-m (165-ft)-wide area around the mounds, from a few meters under the tip of the highest dyke up to the top of the outcrop (Figure 4). The most common clams have been identified by Kiel (2013) as the lucinids Nymphalucina panochensis. In addition, rare, possible mytilids and other species of bivalves are present (Figure 7B, C). Rare tubes found as relatively straight broken segments at least $10 \mathrm{~cm}(0.3 \mathrm{ft})$ long and exhibiting perfectly circular sections less than $1 \mathrm{~cm}$ (0.4 in.) in diameter (enlarging progressively through the segments) are attributed to the Vestimentifera by Schwartz et al. (2003). The density of fossils is approximately $1 / \mathrm{m}^{2}\left(1 / 11 \mathrm{ft}^{2}\right)$. Fossils are undeformed in mounds and are generally found compacted in the surrounding shale.

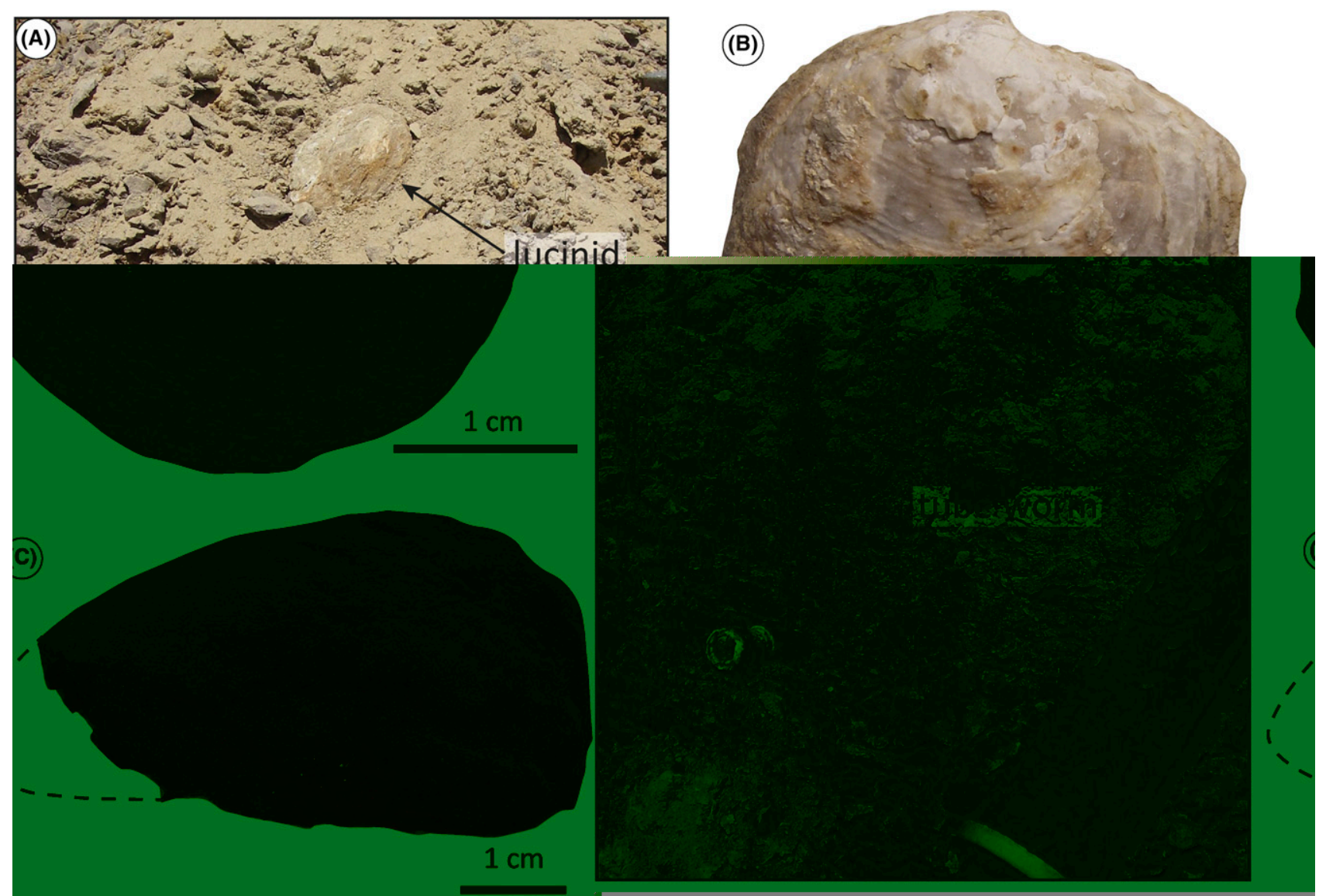

Figure 7. Fauna of outcrop B. (A) A lucinid bivalve in life position and a tube worm. (B) Close-up view of the lucinid Nymphalucina panochensis. (C) An uncommon clam, possibly a mytilid.

\section{PETROGRAPHY OF CARBONATES}

Mounds and nodules from outcrops A and B have very similar microscopic petrography, so they are described together. A detailed petrographic description of all minerals is summarized in Table 1 , following the layout and style of Campbell et al. (2002).

Based on the observed succession of cements and on petrographic and geochemical analyses, the events of the paragenetic sequence have been grouped into early and late diagenetic stages. A similar succession of events can be observed in nodules and concretions of both outcrops A and B, although some cements can be missing locally. The cements are therefore numbered according to the complete (composite) sequence from $\mathrm{N}^{\circ} 1$ to $\mathrm{N}^{\circ} 19$. The succession of cements $\mathrm{N}^{\circ} 3$ to $\mathrm{N}^{\circ} 6$ can repeat several times and define a specific stratigraphic pattern.

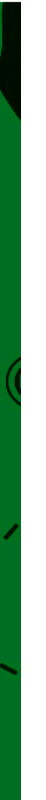




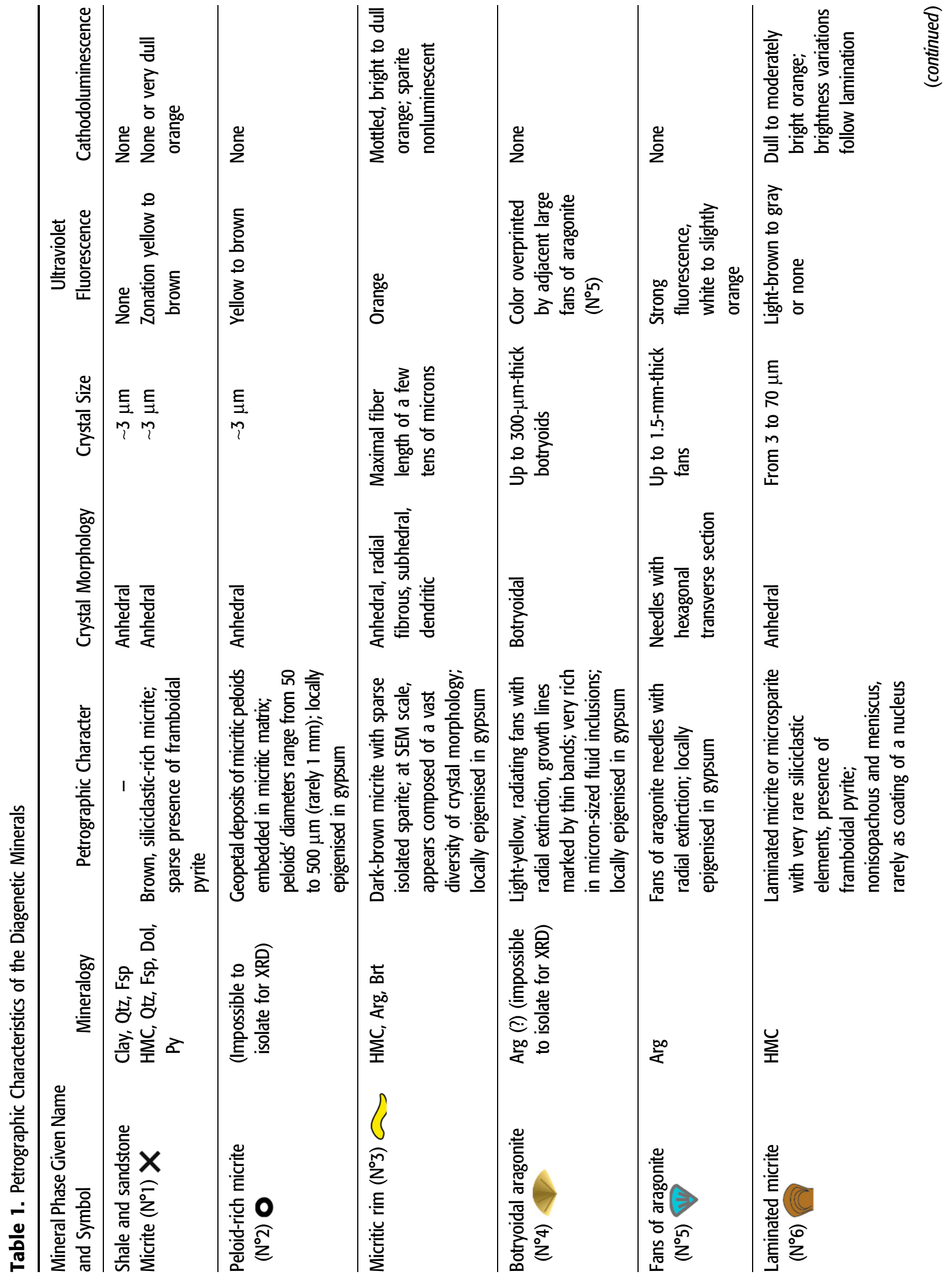




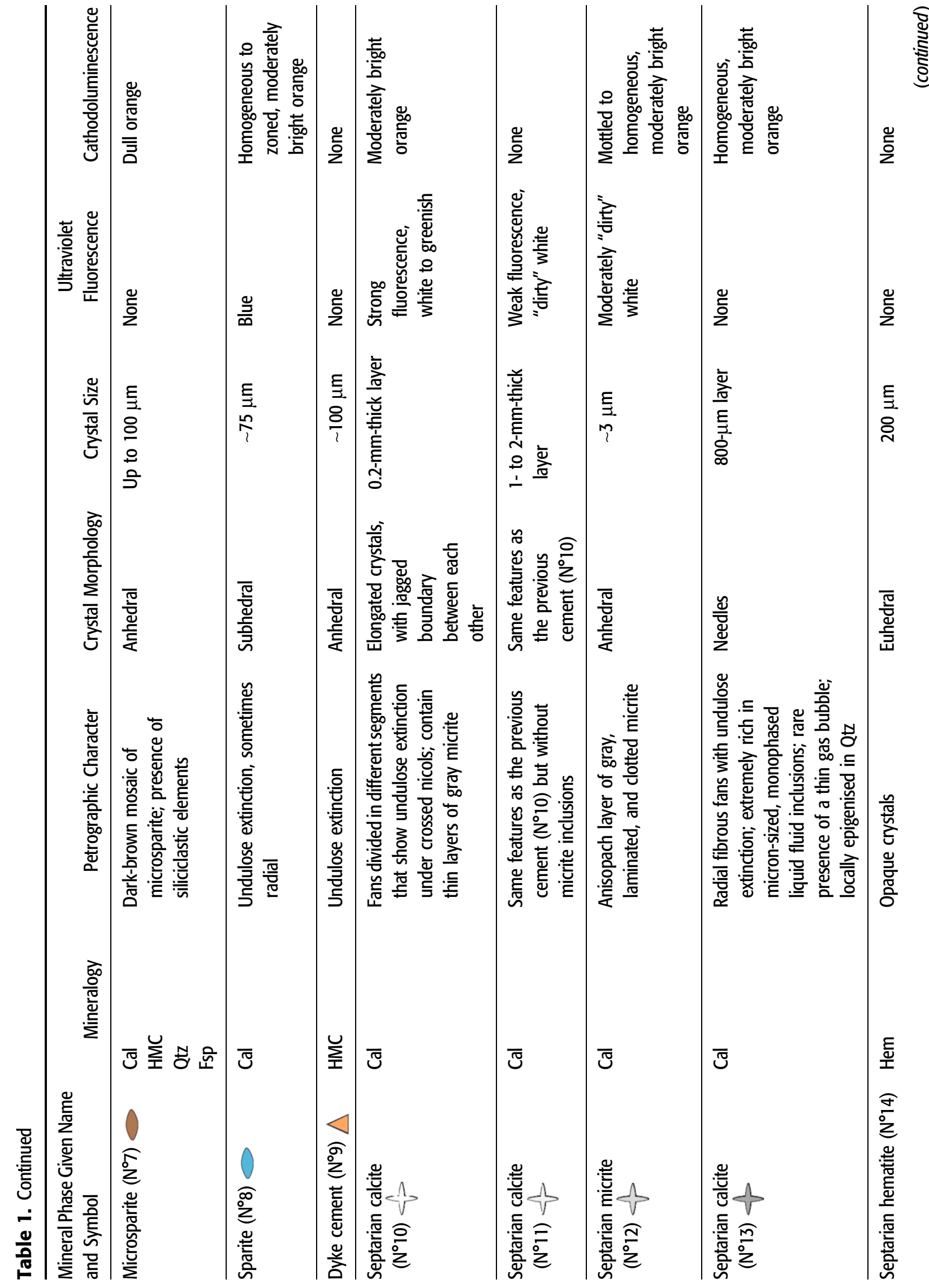




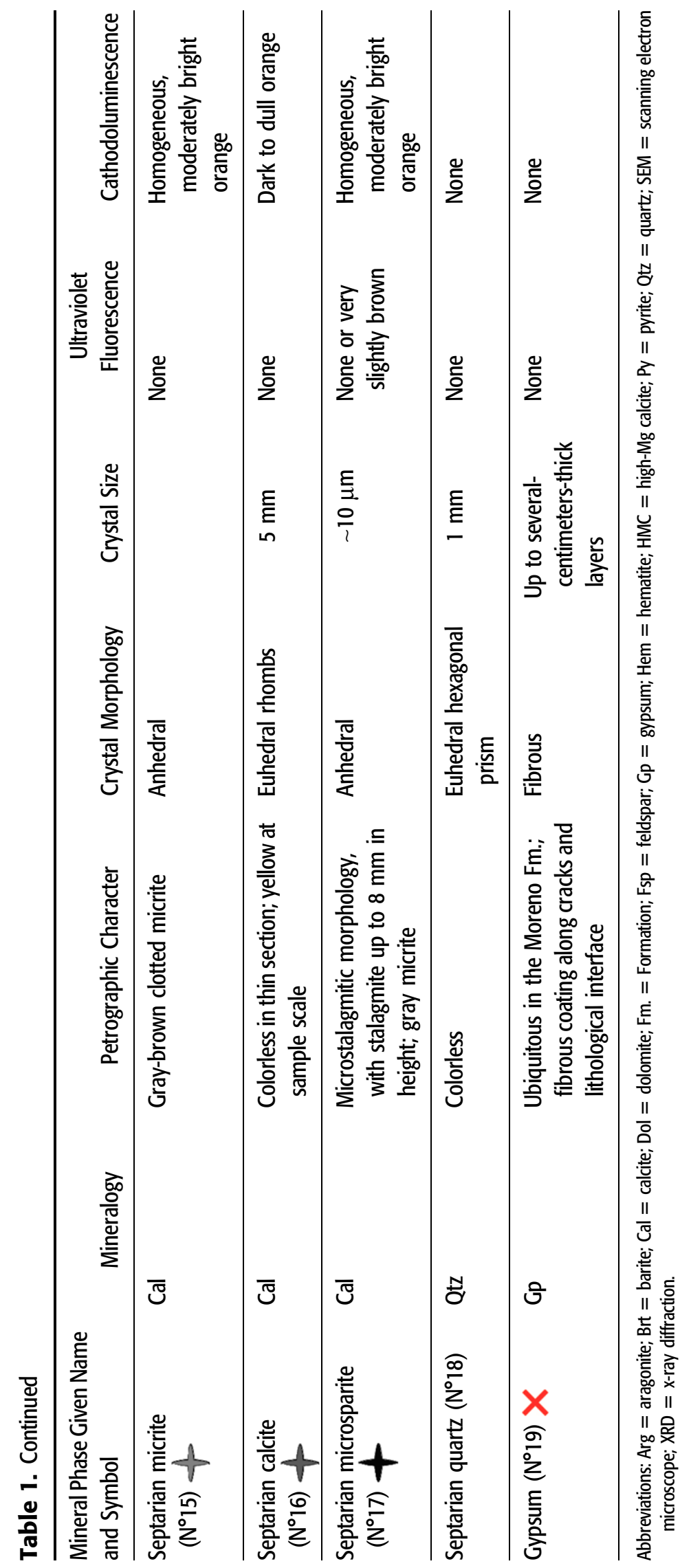




\section{Early Diagenesis}

The volumetrically major phase is a silty micrite $\left(\mathrm{N}^{\circ} 1\right)$. Macroscopically, it corresponds to the nodules and to the gray areas in the mounds. The micrite $\left(\mathrm{N}^{\circ} 1\right)$ is characterized by a strong yellow to brown UV fluorescence. In the mounds, colored zoning can appear as spotty, or locally layered, often organized as concentric rims, especially in cortex of burrows and in spherical concretions (Figure 8A, B).

Different cement generations are present in the cavities and burrows of the micrite $\left(\mathrm{N}^{\circ} 1\right)$.

The infill usually starts with a geopetal layer of a peloid-rich micrite $\left(\mathrm{N}^{\circ} 2\right)$. The diameters of the peloids are heterogeneous and range from $50 \mu \mathrm{m}$ to $1 \mathrm{~mm}$ (Figure 8C). Laterally to the peloid-rich micrite deposits, the sides of the burrows are lined by a micritic rim $\left(\mathrm{N}^{\circ} 3\right)$ covered by botryoidal aragonite $\left(\mathrm{N}^{\circ} 4\right)$ and then, in syntaxial overgrowth, by fans of aragonite $\left(\mathrm{N}^{\circ} 5\right)$ (Figure $\left.8 \mathrm{D}\right)$.

The XRD analyses of the micritic rim $\left(\mathrm{N}^{\circ} 3\right)$ indicate that the volumetrically major phases are high$\mathrm{Mg}$ calcite and aragonite. In addition, SEM coupled to EDS observations reveal a mix of carbonates with high variability of minor cations, including $\mathrm{Mg}, \mathrm{Mn}, \mathrm{Sr}$, and $\mathrm{Fe}$, and the presence of rare crystals of barite (Figure 8E). The morphology of the carbonate crystals at the SEM scale is also variable: micritic, radial fibrous (Figure 8F), subhedral (Figure 8G), and dendritic (Figure 8G, H). Two different morphologies of dendrites have been identified: $5-\mu \mathrm{m}-$ long, randomly oriented, elongated crystals or hieroglyphic crystals several tens of microns in total length.

In the mound of outcrop B, irregular layers of laminated micrite $\left(\mathrm{N}^{\circ} 6\right)$ may cover the aragonite fans $\left(\mathrm{N}^{\circ} 5\right)$ (Figure 9A, B). The coating is meniscate and nongeopetal. It can be locally strongly developed and fills voids. It is locally recrystallized into microsparite ( $\left.\mathrm{N}^{\circ} 7\right)$. Rarely, the laminae can develop around a nucleus (Figure 9B).

The sequence, consisting of micritic rim $\left(\mathrm{N}^{\circ} 3\right)$, botryoidal aragonite $\left(\mathrm{N}^{\circ} 4\right)$, aragonite fans $\left(\mathrm{N}^{\circ} 5\right)$, and laminated micrite $\left(\mathrm{N}^{\circ} 6\right)$, may repeat up to approximately 10 times (Figure 9C). This repetitive sequence will hereafter be referred to as the elementary sequence (ES).

A trend can be observed from the earliest to the latest ES: the micritic rims $\left(\mathrm{N}^{\circ} 3\right)$ decrease in thickness, whereas the aragonite fans $\left(\mathrm{N}^{\circ} 5\right)$ thicken, and the laminated micrite $\left(\mathrm{N}^{\circ} 6\right)$ that is often absent in the earliest ES becomes more common (Figure 9A, C).
The boundary between two successive ESs can be marked by a truncation of the minerals showing dissolution features (Figure 9D, E).

\section{Late Diagenesis}

The microsparite $\left(\mathrm{N}^{\circ} 7\right)$ constitutes a mosaic of crystals (Figure 9C). It does not fluoresce and thus is distinguishable from all earlier cements (Figure 8B). In places, the microsparite $\left(\mathrm{N}^{\circ} 7\right)$ contains cracks, a few millimeters to centimeters long, filled with sparite $\left(\mathrm{N}^{\circ} 8\right)$.

In the mounds, at the macroscopic scale, this microsparite $\left(\mathrm{N}^{\circ} 7\right)$ constitutes the brown to greenish areas. It is volumetrically the most important phase of the mounds together with micrite $\left(\mathrm{N}^{\circ} 1\right)$. The microsparite $\left(\mathrm{N}^{\circ} 7\right)$ appears to surround the concretions of micrite $\left(\mathrm{N}^{\circ} 1\right)$, cementing the mound (Figure 5). Locally, angular clasts of micrite $\left(\mathrm{N}^{\circ} 1\right)$ are embedded in the microsparite $\left(\mathrm{N}^{\circ} 7\right)$, resulting in a breccia texture (Figures 5C, 10A).

Randomly oriented septarian cracks up to $50 \mathrm{~cm}$ (20 in.) long crosscut all earlier cements of the mounds (Figure 10A). In one representative and thick septarian crack from outcrop A, we observed four generations of sparite $\left(\mathrm{N}^{\circ} 10, \mathrm{~N}^{\circ} 11, \mathrm{~N}^{\circ} 13\right.$, $\left.\mathrm{N}^{\circ} 16\right)$, two generations of micrite $\left(\mathrm{N}^{\circ} 12, \mathrm{~N}^{\circ} 15\right)$, one generation of hematite $\left(\mathrm{N}^{\circ} 14\right)$, one generation of microsparite $\left(\mathrm{N}^{\circ} 17\right)$, and one generation of quartz $\left(\mathrm{N}^{\circ} 18\right)$. The microsparite $\left(\mathrm{N}^{\circ} 17\right)$ has a microstalagmitic morphology, with the largest observed stalagmite up to $8 \mathrm{~mm}$ (0.3 in.) in height (Figure 10B).

\section{STABLE ISOTOPE GEOCHEMISTRY}

\section{Stable Isotopes}

The results of stable carbon and oxygen isotope analyses of the studied carbonate phases from outcrops A and $B$ are summarized in the Appendix and plotted in Figure 11.

The material analyzed corresponds to the volumetrically most important carbonate phases: micrite $\left(\mathrm{N}^{\circ} 1\right)$, peloid-rich micrite $\left(\mathrm{N}^{\circ} 2\right)$, aragonite fans $\left(\mathrm{N}^{\circ} 5\right)$, laminated micrite $\left(\mathrm{N}^{\circ} 6\right)$, microsparite $\left(\mathrm{N}^{\circ} 7\right)$, sparite $\left(\mathrm{N}^{\circ} 8\right)$, and all carbonate cements of the septarian cracks $\left(\mathrm{N}^{\circ} 10\right.$ to $\left.\mathrm{N}^{\circ} 17\right)$. Volumetrically minor phases of carbonate cements were 

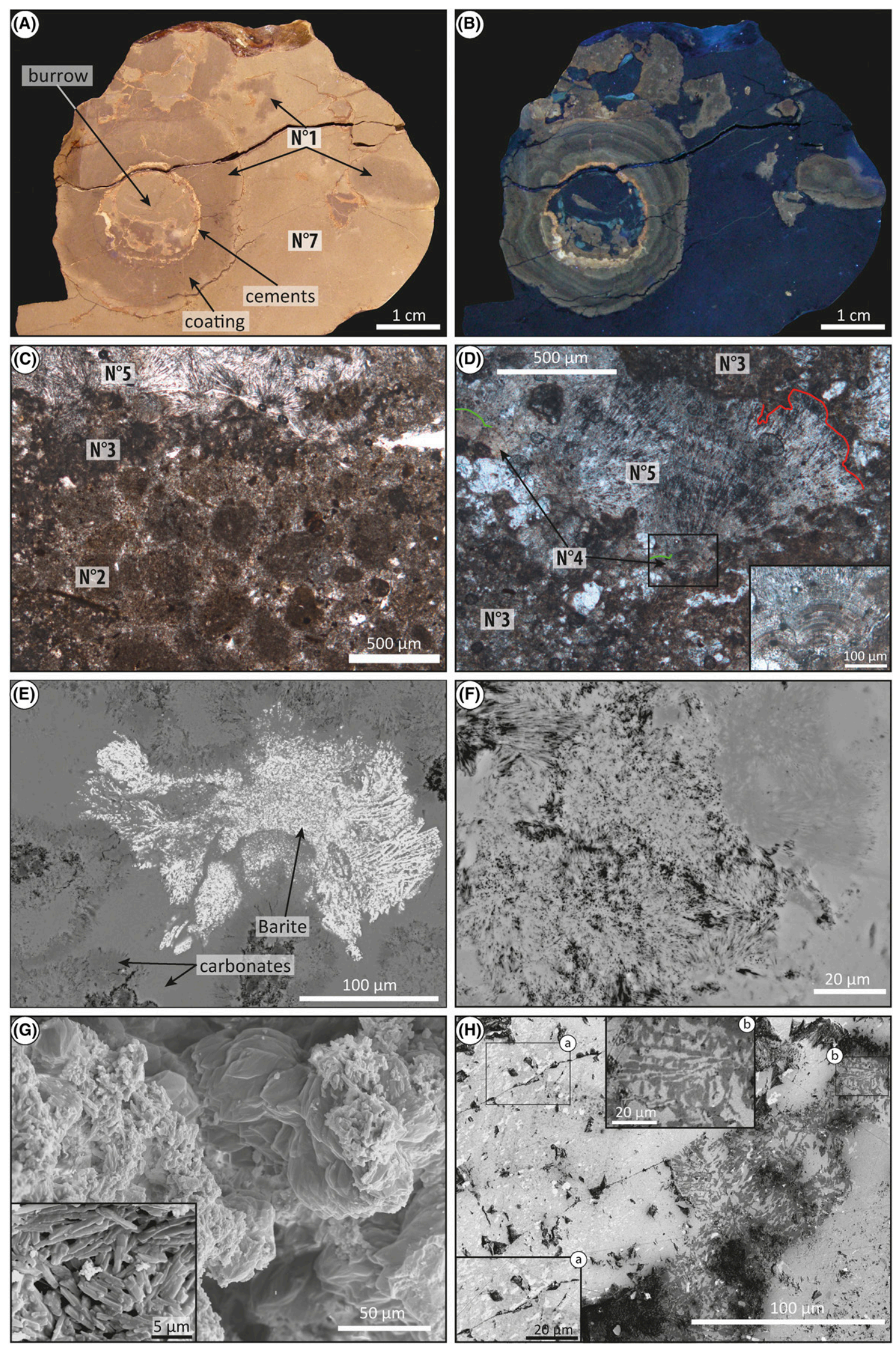
impossible to isolate because of the limited ability of the microdrill to recover very small amounts; however, a mix of some minor phases was obtained and analyzed. Two samples of cements of the sandstone dykes were analyzed.

Isotopic signatures are characteristic of each phase and, for a given phase, the isotopic signature is identical for both outcrops A and B. Data from both outcrops are plotted together and not distinguished in Figure 11. The data cluster in three fields. The first cluster is characterized by extremely low $\delta^{13} \mathrm{C}$ values $(-38.15 \%$ to $50.94 \% 0)$ and the highest $\delta^{18} \mathrm{O}$ values $(0.21 \%$ to 2.09\%o). It comprises the early diagenetic phases: micrite $\left(\mathrm{N}^{\circ} 1\right)$, peloid-rich micrite $\left(\mathrm{N}^{\circ} 2\right)$, micritic rim $\left(\mathrm{N}^{\circ} 3\right)$, botryoidal aragonite $\left(\mathrm{N}^{\circ} 4\right)$, and aragonite fans $\left(\mathrm{N}^{\circ} 5\right)$. Carbonate samples partially transformed to gypsum deviate from the cluster of gypsum-free carbonate but plot in the same general area of the diagram.

A second cluster has $\delta^{13} \mathrm{C}$ and $\delta^{18} \mathrm{O}$ values close to marine values (respectively, from $3.64 \%$ to $-3.68 \%$ o and from $0.99 \%$ to $-0.52 \% 0$ ). It comprises microsparite $\left(\mathrm{N}^{\circ} 7\right)$, sparite $\left(\mathrm{N}^{\circ} 8\right)$, dyke cement $\left(\mathrm{N}^{\circ} 9\right)$, and the earliest cements of the septarian cracks $\left(\mathrm{N}^{\circ} 10\right.$ $\left.\mathrm{N}^{\circ} 12\right)$. The laminated micrite $\left(\mathrm{N}^{\circ} 6\right)$ and a few samples of microsparite $\left(\mathrm{N}^{\circ} 7\right)$ are scattered in between the above-cited clusters.

A third cluster is composed of the late phases of infill of the septarian cracks $\left(\mathrm{N}^{\circ} 13, \mathrm{~N}^{\circ} 15, \mathrm{~N}^{\circ} 16\right.$, and $\left.\mathrm{N}^{\circ} 17\right)$, characterized by slightly depleted $\delta^{13} \mathrm{C}$ values $(-4.99 \%$ to $-7.65 \%$ o $)$ and low, but variable, $\delta^{18} \mathrm{O}$ values $(-2.19 \%$ to $-6.06 \%)$.

\section{INTERPRETATION}

The very low $\delta^{13} \mathrm{C}$ values of the early carbonate cements $\left(\mathrm{N}^{\circ} 1-\mathrm{N}^{\circ} 6\right)$ characterize methane-derived authigenic carbonate (MDAC) precipitated from the archeal AOM combined with bacterial sulfate reduction in the SMTZ (Boetius et al., 2000; Peckmann and Thiel, 2004).

The fauna from outcrop B, tube worms, lucinids, and certain mytilids are typical chemosynthetic animals (Kiel, 2010). They harbor chemoautotrophic, sulfur-oxidizing bacteria that allow them to obtain energy and nutrients in hydrocarbon seep environment. Moreover, this symbiotic association is presumed to be essential for all species of the lucinid family (Taylor and Glover, 2010).

The first mineral with a clear marine isotopic signature is the microsparite $\left(\mathrm{N}^{\circ} 7\right)$; we therefore consider it to mark the beginning of a second phase of diagenesis, after deactivation of AOM (Figure 12).

The septarian cracks record a succession of minerals from marine to meteoric isotopic signatures. The microstalagmitic morphology of one of the later cements, with a meteoric signature, indicates precipitation in the meteoric vadose zone. The last cements therefore correspond to a third phase marked by the influx of meteoric water into the system.

\section{DISCUSSION: SEEPAGE PROCESSES REVEALED BY THE PARAGENETIC SEQUENCE OF AUTHIGENIC CARBONATES}

\section{Authigenic Carbonate Precipitation Mechanisms}

\section{Micrite $\left(\mathrm{N}^{\circ} 1\right)$}

The infill of burrows by methane-derived cements suggests that burrows acted as open pathways for focused hydrocarbon flow. Their coating by a cortex of micrite $\left(\mathrm{N}^{\circ} 1\right)$ is interpreted to result from the slow diffusion of methane into the immediately surrounding sediment (Wiese et al., 2015). The presence of detrital grains in the micrite $\left(\mathrm{N}^{\circ} 1\right)$

Figure 8. Petrographic features of early diagenetic minerals. (A) Polished slice of a mound sample: gray nodules (micrite $\mathrm{N}^{\circ} 1$ ) are embedded within the brown matrix (microsparite $\mathrm{N}^{\circ} 7$ ). The indicated burrow is coated by micrite $\left(\mathrm{N}^{\circ} 1\right.$ ) and lined by cements. (B) View of the same sample under ultraviolet light. Micrite $\left(\mathrm{N}^{\circ} 1\right)$ is strongly fluorescent, visualizing concentric rims around the burrow. (C) Peloid-rich micrite $\left(\mathrm{N}^{\circ} 2\right)$ covered by a micritic rim $\left(\mathrm{N}^{\circ} 3\right)$ and aragonite fans $\left(\mathrm{N}^{\circ} 5\right)$. (D) Typical succession of minerals forming the elementary sequence (ES): micritic rim $\left(\mathrm{N}^{\circ} 3\right)$, botryoidal aragonite $\left(\mathrm{N}^{\circ} 4\right)$, and fans of aragonite $\left(\mathrm{N}^{\circ} 5\right)$. The upper part of the aragonite fans is corroded (underlined by the red sinuous line). (E) Backscattered electron-scanning electron microscope (BSE-SEM) picture showing the micritic rim ( $\mathrm{N}^{\circ} 3$ ) composed of fibrous barite and several carbonate phases. (F) A BSE picture of the micritic rim ( $\mathrm{N}^{\circ} 3$ ) showing fibrous carbonates. (G) An SEM picture showing the micritic rim ( $\mathrm{N}^{\circ} 3$ ) with subhedral crystals covered by randomly orientated elongated crystals. The insert shows a representative example of the elongate crystals at a higher magnification. (H) A BSE picture of the micritic rim ( $\left.\mathrm{N}^{\circ} 3\right)$. Detail a shows bright (Sr-rich), aligned, elongated crystals. Detail b shows dark (Mg- and Mn-rich), dendritic crystals. Note: A color version can be seen in the online version. 

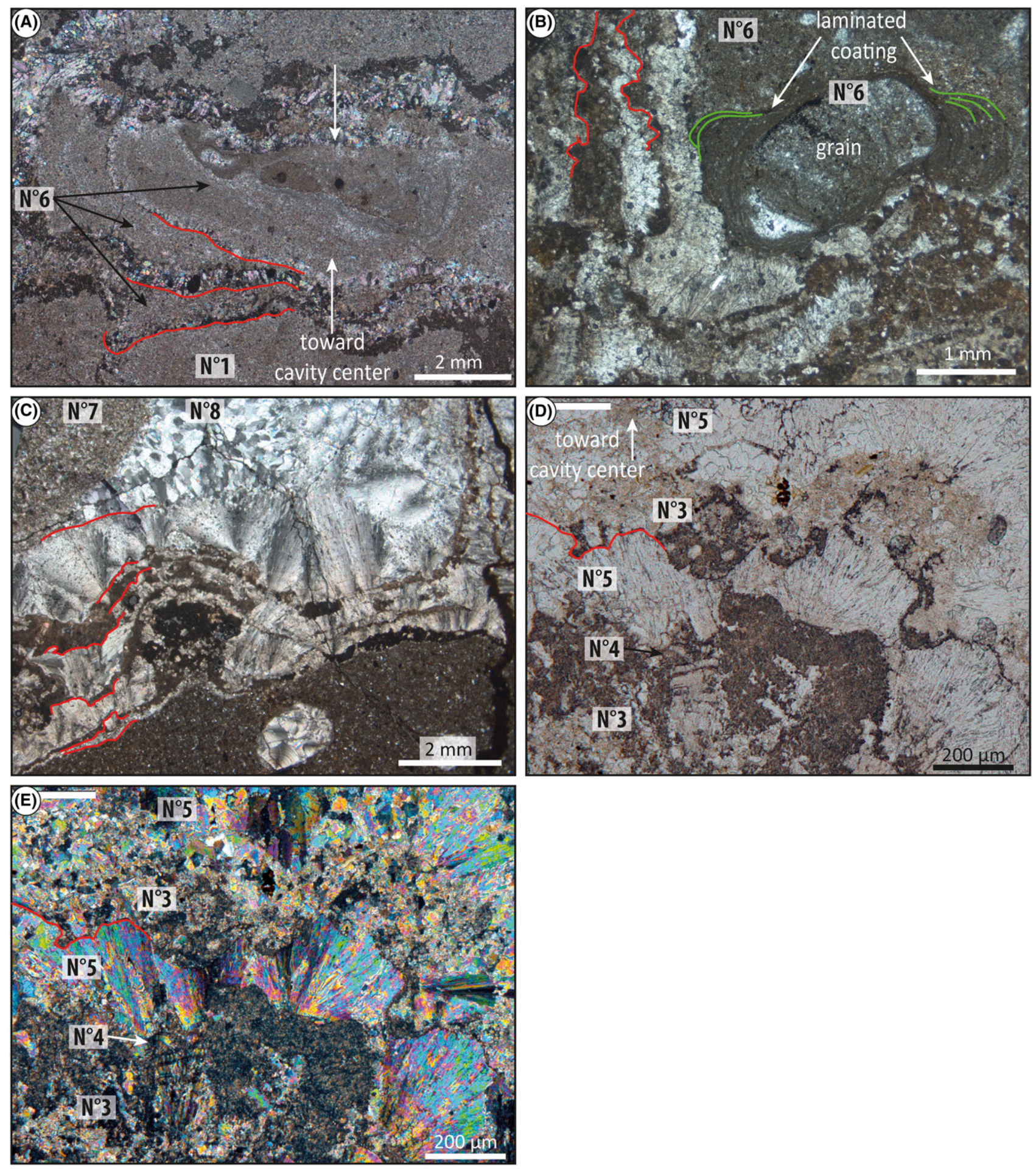

Figure 9. Petrographic features of early diagenetic minerals. (A) Three elementary sequences (ESs) terminating with a layer of laminated micrite $\left(\mathrm{N}^{\circ} 6\right)$. The laminated micrite $\left(\mathrm{N}^{\circ} 6\right)$ of the last sequence occludes the cavity. The base of each $\mathrm{ES}$ is highlighted by a red line. (B) Several ESs terminating with corroded aragonite fans. The last ES ends with a thick cover of laminated micrite $\left(\mathrm{N}^{\circ} 6\right)$ hosting a coated grain (green line underlining the lamination). (C) At least six well-developed ESs. The aragonite fans of the last sequence are well developed. (D) Corroded aragonite fans at the boundary between two ESs. (E) Same picture under crossed nicols. Note: A color version can be seen in the online version. 

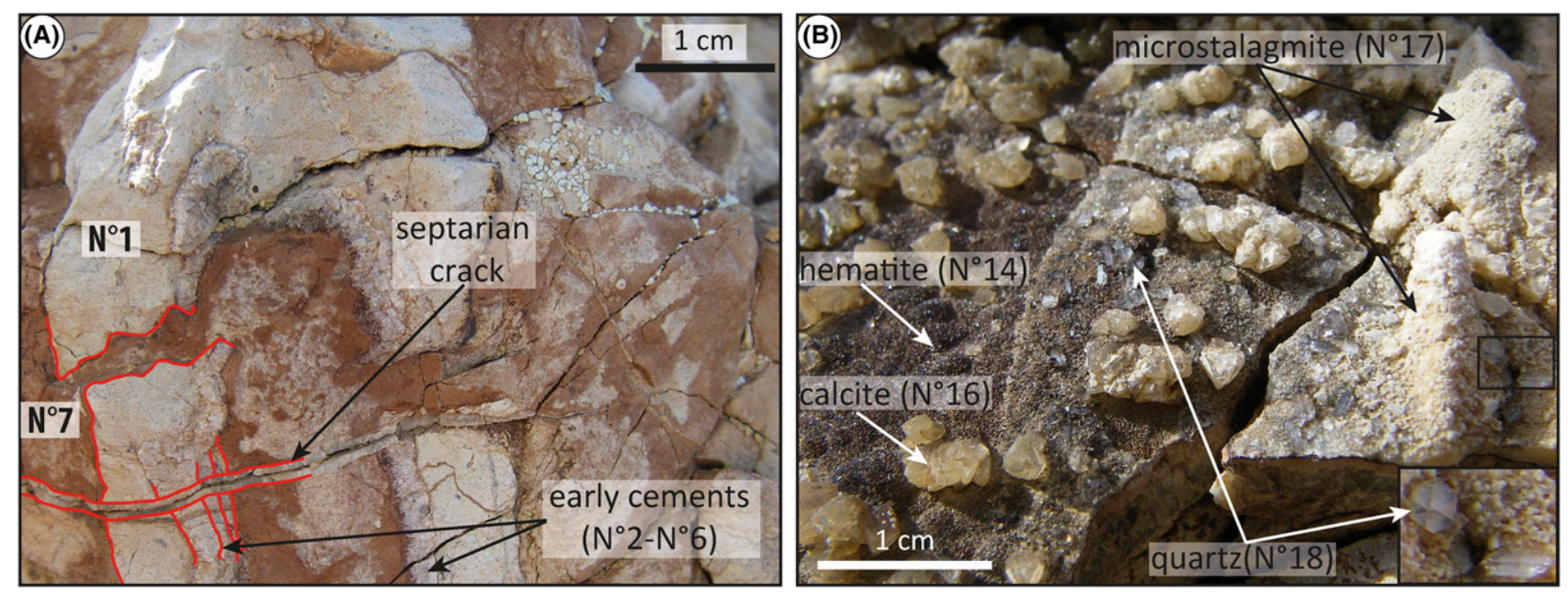

Figure 10. Late diagenetic minerals. (A) Burrow coated by micrite $\left(\mathrm{N}^{\circ} 1\right)$ and lined by early cements $\left(\mathrm{N}^{\circ} 2-\mathrm{N}^{\circ} 6\right)$. Both have been crosscut by a crack filled by microsparite $\left(\mathrm{N}^{\circ} 7\right)$ and later by a septarian crack. (B) Surface of a well-developed septarian crack covered by hematite $\left(\mathrm{N}^{\circ} 14\right)$, sparite $\left(\mathrm{N}^{\circ} 16\right)$, microsparite $\left(\mathrm{N}^{\circ} 17\right)$ with a microstalagmitic morphology, and euhedral quartz $\left(\mathrm{N}^{\circ} 18\right)$.

indicates that it precipitated within the porous network of the siliciclastic sea floor sediment. In addition, the preservation within the micrite $\left(\mathrm{N}^{\circ} 1\right)$ of noncompacted bivalves and burrows proves that carbonate precipitated at shallow burial depth, before any significant compaction of the sediment occurred.

The peloids $\left(\mathrm{N}^{\circ} 2\right)$ present at the bottom of burrows occur as one episode, before the earliest ES, suggesting that they are fecal pellets deposited while the burrow was still in use by the organism.

\section{The Elementary Sequence}

The repetition (up to 10 times) of a consistent mineral succession in the early diagenetic stage indicates that a cyclic fluid flow sequence took place.

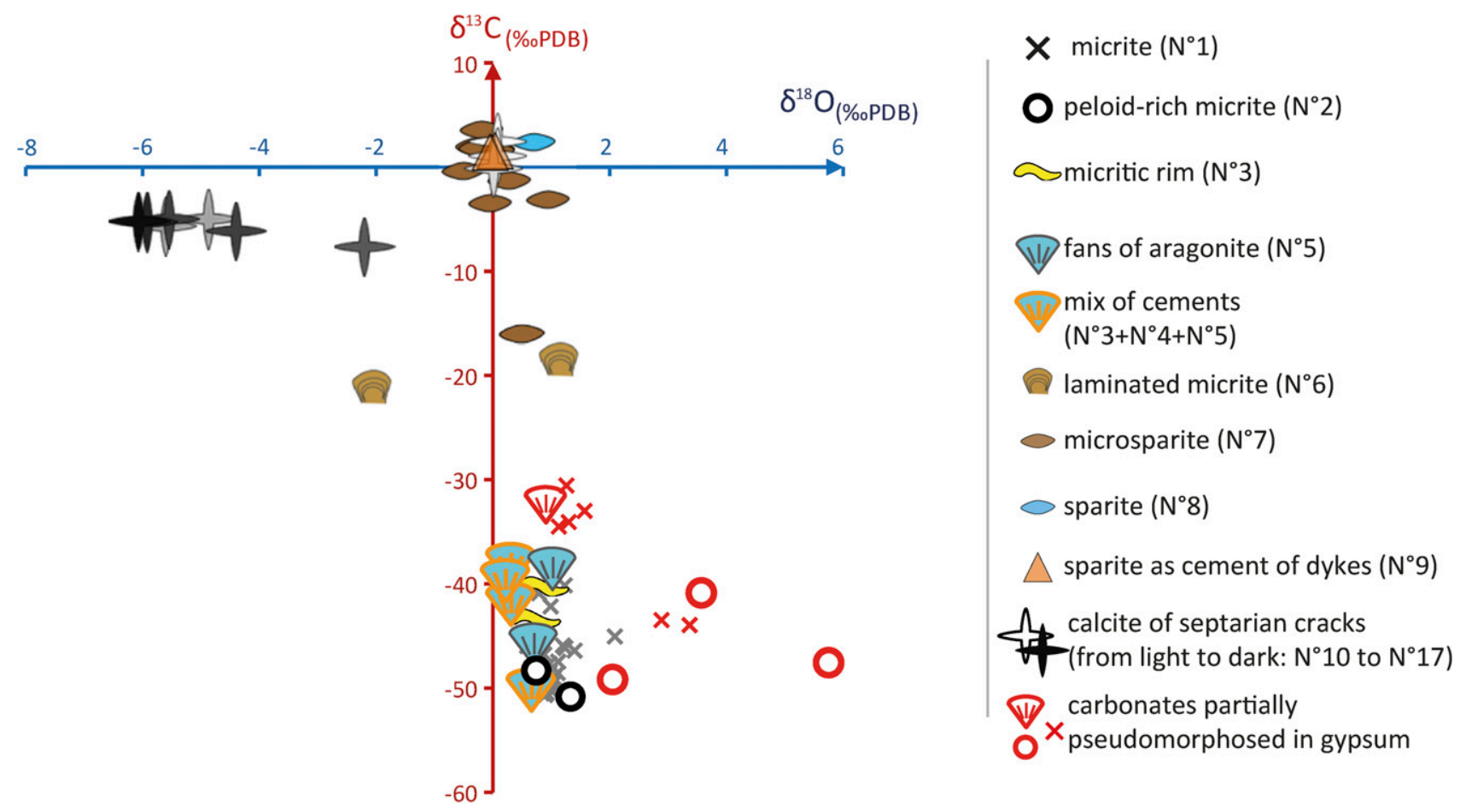

Figure 11. Stable isotopes of carbonate phases. $\mathrm{PDB}=$ Peedee belemnite. 


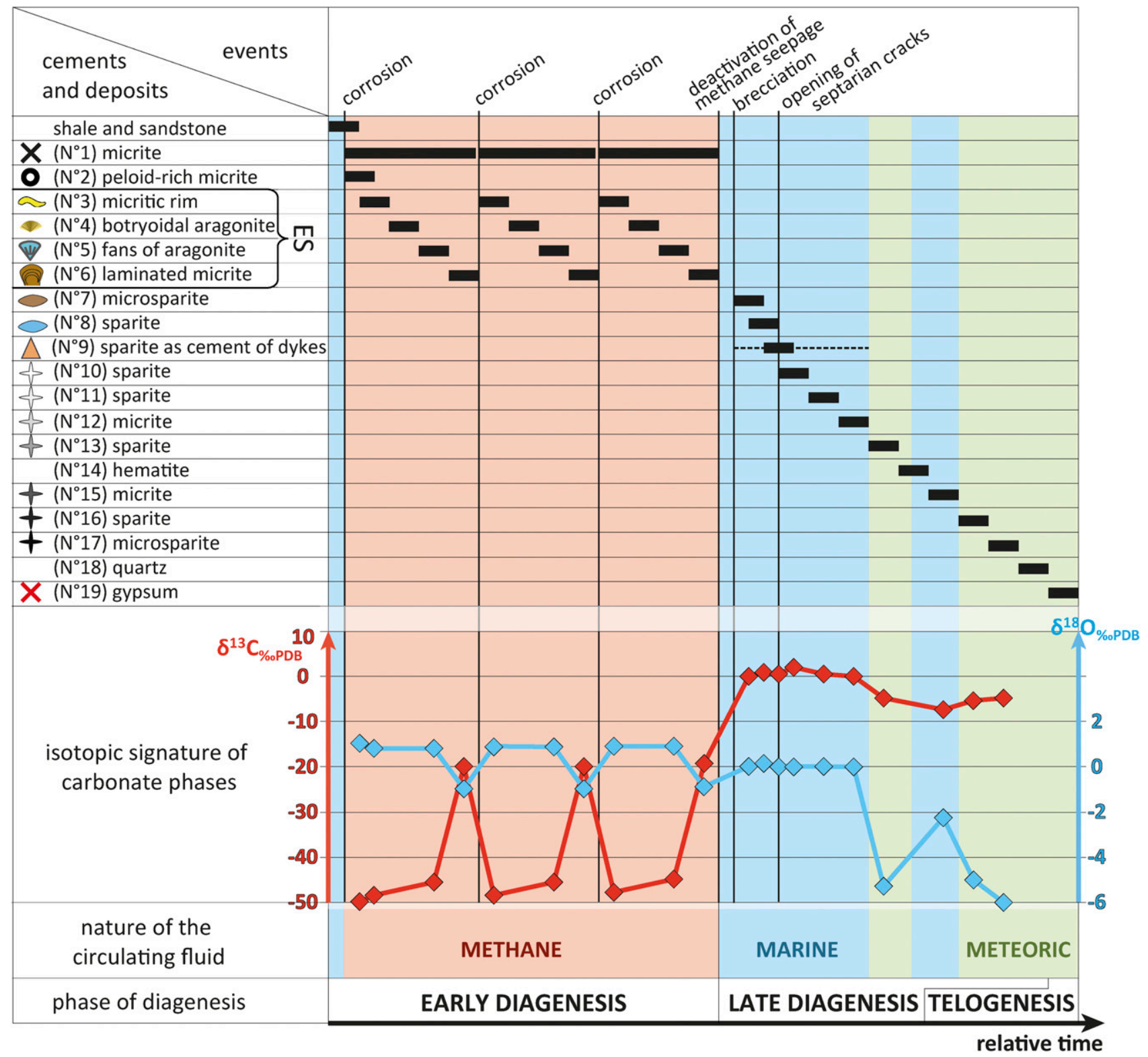

Figure 12. Paragenetic sequence observed in outcrops $A$ and $B$. In this example, three elementary sequences (ES) are represented. The average stable isotope signature of each analyzed carbonate phase is indicated. The succession of three types of diagenetic fluids can be distinguished: methane, marine, and meteoric waters. Beginning of late diagenesis is marked by the first marine cement; telogenesis corresponds to the precipitation of gypsum. PDB $=$ Peedee belemnite.

The growth rings visible under UV light in the micritic cortex of the tubes $\left(\mathrm{N}^{\circ} 1\right)$ may result from the same phenomenon.

Element 1 of the Elementary Sequence: Corrosion Surface The corrosion surface, which commonly marks the beginning of the individual ESs (Figure 9D, E), indicates circulation of a fluid undersaturated with respect to carbonate. Observations of corrosion surfaces, frequently lined by pyrite, are common in seep carbonates (Campbell et al., 2002). This is explained by the migration of acidic $\mathrm{H}_{2} \mathrm{~S}$ from the SMTZ followed by a reaction with $\mathrm{Fe}^{2+}$ (Campbell, 2006). The absence of pyrite in our particular case may indicate that the amount of available iron from the sediment was too low to promote extensive pyrite precipitation, but it cannot explain why the corrosion is systematically associated with the first stage of the ESs. Another explanation for the promotion of carbonate dissolution, 
without pyrite precipitation, is the increase in acidity associated with the reaction of aerobic oxidation of methane (Reeburgh, 2007) according to the following equation:

$$
\mathrm{CH}_{4}+2 \mathrm{O}_{2} \leftrightarrow \mathrm{CO}_{2}+2 \mathrm{H}_{2} \mathrm{O}
$$

The following model is proposed in support of the aerobic oxidation of methane. At an initial steady state, without external input of methane, the SMTZ was probably localized at a certain depth within the sediment ("passive SMTZ" of Regnier et al., 2011) while the upper part of the sediment was normally oxygenated. In a second stage, a burst of methane from below rose up into the subseafloor oxic zone. Aerobic oxidation of methane then took place until all available oxygen was consumed. Meanwhile, the diagenetic horizon stabilized in a new equilibrium position, above the previous one. In the case where the methane flux was strong enough to consume all the oxygen in the sediment, the SMTZ may even have risen up to the sea floor.

\section{Element 2 of the Elementary Sequence: Micritic Rim (N³)} The minerals constituting the micritic rim $\left(\mathrm{N}^{\circ} 3\right)$ are the first authigenic precipitates found within the burrows. The great diversity of mineralogies and mineral fabrics may reflect either frequent variations in the physicochemical parameters of the fluid (temporal variability) or small-scale partitioning into several microenvironments (spatial variability). Similar variations in carbonate fabrics induced by very local conditions are observed in modern bacterial mats (Riding, 2000).

The presence of barite in association with seep carbonates is not uncommon (e.g., Greinert et al., 2002; Aloisi et al., 2004; Feng and Roberts, 2011). Barium contained in cold seep fluids is often thought to originate from the dissolution of barite contained in deeper buried sediment, below the sulfate depletion level (SMTZ) of marine sediments (Torres et al., 2003; Arning et al., 2015). Sediments rich in biogenic barite are associated with high biologically productive oceans (Stroobants et al., 1991), as was the case during deposition of the Moreno Formation (Fonseca-Rivera, 1997). The Moreno Formation was most probably the source of barium.

The dendritic morphology of some crystals (Figure $8 \mathrm{H}$ ) is typical of a very rapid growth rate in a fluid highly oversaturated with respect to carbonates. This indicates an intense AOM activity probably fed by a high hydrocarbon supply. This situation corresponds to the "active SMTZ" described by Regnier et al. (2011). In comparison with the previous stage of corrosion, all the oxygen would have been consumed, and the SMTZ would have risen up to a shallower depth in the sediment.

\section{Element 3 of the Elementary Sequence: Botryoidal Aragonite} $\left(\mathrm{N}^{\circ} 4\right)$ and Aragonite Fans $\left(\mathrm{N}^{\circ} 5\right)$

The next precipitates consist of aragonite, first botryoidal $\left(\mathrm{N}^{\circ} 4\right)$ and then in fans of needles $\left(\mathrm{N}^{\circ} 5\right)$. From the micritic rim $\left(\mathrm{N}^{\circ} 3\right)$ to the aragonitic botryoids and fans $\left(\mathrm{N}^{\circ} 4\right.$ and $\left.\mathrm{N}^{\circ} 5\right)$, we observed that the mineralogical diversity decreased drastically, with disappearance of the dendritic morphology and increase in crystal size by two orders of magnitude. This suggests that crystals grew more slowly during a relatively long period of time. Therefore, the degree of oversaturation of the fluid decreased, as well as the rate of AOM. Moreover, in seep carbonate environments, aragonite is often associated with "near sea floor conditions" (Burton, 1993; Aloisi et al., 2000; Bayon et al., 2007). Thus, this may reflect a deepening of the SMTZ associated with the decrease of hydrocarbon flux. As a whole, it suggests a relatively long period of low fluid flux and a deepening of the SMTZ during the growth ofbotryoidal aragonite $\left(\mathrm{N}^{\circ} 4\right)$ and aragonite fans $\left(N^{\circ} 5\right)$.

\section{Element 4 of the Elementary Sequence: Laminated Micrite $\left(\mathrm{N}^{\circ} 6\right)$}

The laminated micrite $\left(\mathrm{N}^{\circ} 6\right)$ is not geopetal; it cannot have been deposited as detrital input and is therefore authigenic. It lines pore rims, as can be expected for biofilms (Reitner et al., 2005), and so the lamination could constitute a stromatolitic texture (e.g., Greinert et al., 2002; Agirrezabala, 2009). Such microbial deposits within cavities have been described as autoendoliths by Marlow et al. (2015).

No general established relationship exists between flux rate and stromatolitic texture. However, the decreasing trend of flux within the ES would tend to demonstrate that these stromatolites may correspond to a moribund stage of seepage activity. 


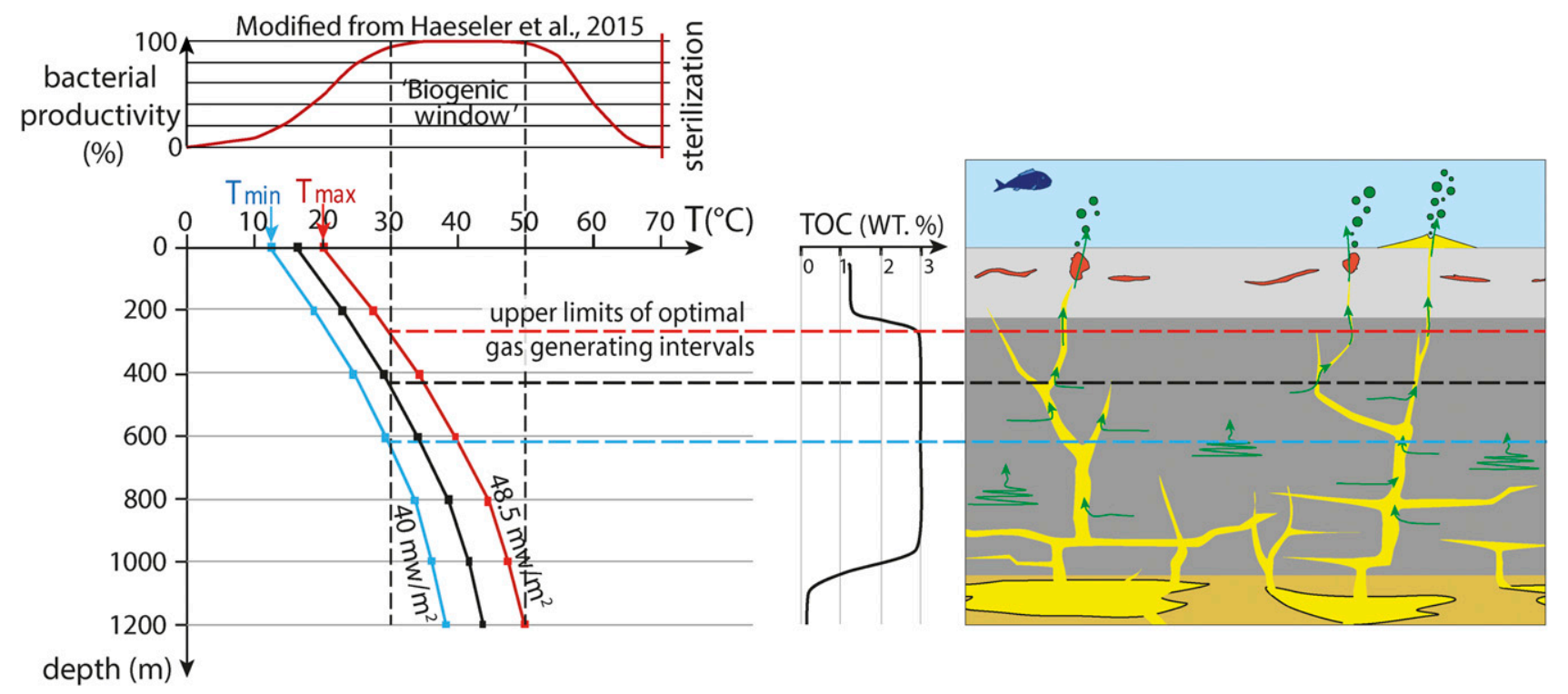

Figure 13. One-dimensional thermal model of the Moreno Formation at the time of seep carbonate precipitation. Three cases have been calculated using the minimum, average, and maximum values of sea-floor temperature $\left(T_{\min }-T_{\max }\right)$ and heat flow taken from literature (see references in text). The curve of bacterial activity as a function of temperature is from Haeseler et al. (2015). The three upper limits of the optimal biogenic gas window were calculated at 200, 400, and $600 \mathrm{~m}$ below sea floor. $\mathrm{T}=$ temperature; TOC $=$ total organic carbon.

\section{Seepage Cycles}

To conclude, each ES is interpreted as a record of one seepage cycle corresponding to the evolution from a sudden strong hydrocarbon pulse that pushed the SMTZ upward to a decrease of flux intensity and a deepening of the SMTZ over a longer period of time. The repetition of ESs precipitation is therefore inferred to correspond to the repetition of methane pulses. The overall evolution observed in successive ESs, as described in the Early Diagenesis section, suggests that the energy of methane pulses decreased at the scale of the seepage's life span.

\section{Late Diagenesis}

Microsparite $\left(\mathrm{N}^{\circ} 7\right)$ likely formed as an aggrading in situ replacement of an earlier micrite (Bathurst, 1971; Campbell et al., 2002), as also suggested by the presence of shrinkage cracks filled with calcite $\left(\mathrm{N}^{\circ} 8\right)$. This micrite precipitated around the MDAC concretions, cementing the mound; it is conceivable that the MDAC acted as a substrate, thus favoring the heterogeneous nucleation of micrite (De Yoreo and Vekilov, 2003).

Laminated micrite $\mathrm{N}^{\circ} 6$ locally recrystallized to microsparite. This phenomenon is associated with a shift in isotopic signatures between the MDAC and the marine values. On the contrary, the microsparite $\left(\mathrm{N}^{\circ} 8\right)$ has a clear marine isotope signature, thus we favor the hypothesis that its initial signature was marine. The local breccia texture composed of MDAC clasts embedded within the microsparite $\left(\mathrm{N}^{\circ} 7\right)$ indicates hydraulic fracturing under isotropic stress conditions (Cosgrove, 1997). This implies a closed or semiclosed fluid system.

The isotopic trend observed in the cements of septarian cracks, from marine to meteoric fluids, probably results from the progressive infill of the Great Valley Basin up to its current exhumation. Presumably, the Franciscan subduction complex that continually rose up and began to emerge in the Paleogene (McGuire, 1988; Fonseca-Rivera, 1997) favored lateral fluid flow from west to east through permeable sandy intervals such as the Cima Sandstone Lentil.

Gypsum precipitation is attributed to epigenetic oxidation of pyrite contained in shales (Presser and Swain, 1990). It locally and partially neomorphosed MDAC, thereby leading to a complete loss of UV fluorescence and a shift in isotopic signature toward higher $\delta^{13} \mathrm{C}$ values and randomly scattered $\delta^{18} \mathrm{O}$ values. 


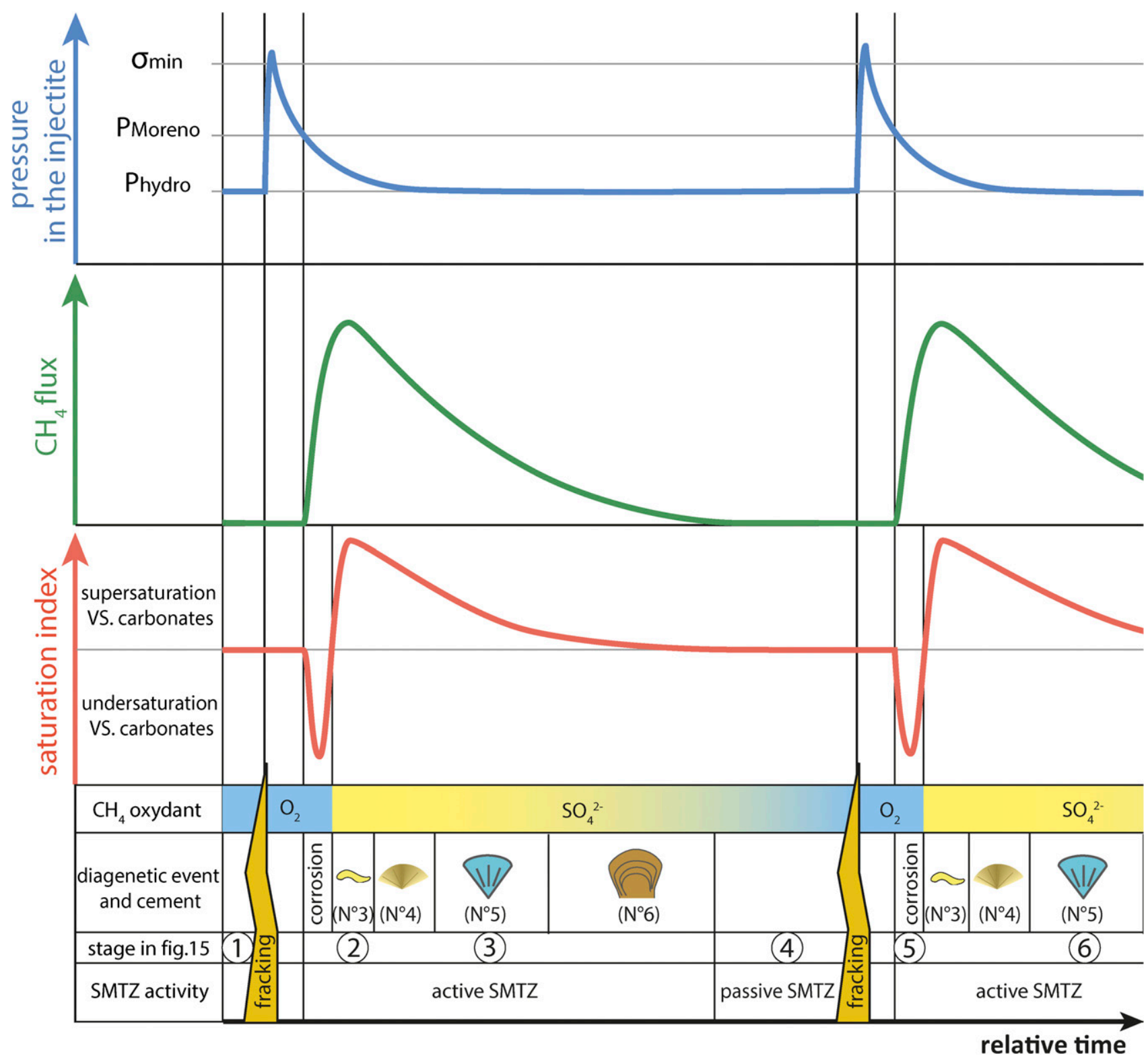

Figure 14. Relation between evolution of pressure in the injectite network, flux of methane, and precipitation of seep carbonates. Here $\sigma_{\min }$ is the minimal stress, the critical value necessary to open a fracture; $P_{\text {Moreno }}$ is the pore pressure in the Moreno Formation; and $P_{\text {hydro }}$ is the hydrostatic pressure. SMTZ = sulfate-methane transition zone.

\section{PETROLEUM SYSTEM LINKED TO GAS SEEPAGE}

\section{Origin of the Hydrocarbons That Fed the Methane-Derived Authigenic Carbonate}

Measurements in modern seeps have shown that the $\delta^{13} \mathrm{C}$ value of seep carbonates is almost always higher than the hydrocarbons' $\delta^{13} \mathrm{C}$ value from which they derive (Peckmann and Thiel, 2004). In our case, the measured $\delta{ }^{13} \mathrm{C}$ values of MDAC, as low as $-50.94 \%$, indicate an origin from the oxidation of biogenic methane (cf. Peckmann and Thiel, 2004). As mentioned in the Geological Setting section, the only source rock deposited before the Cima Sandstone Lentil in the studied region is the Moreno Formation; its 3\% TOC content is largely sufficient to promote biogenic gas generation (Clayton, 1992). Therefore, it is relevant to consider whether the Moreno Formation was under the right conditions to generate biogenic gas when the MDACs formed. The following paragraphs aim at solving this issue. 

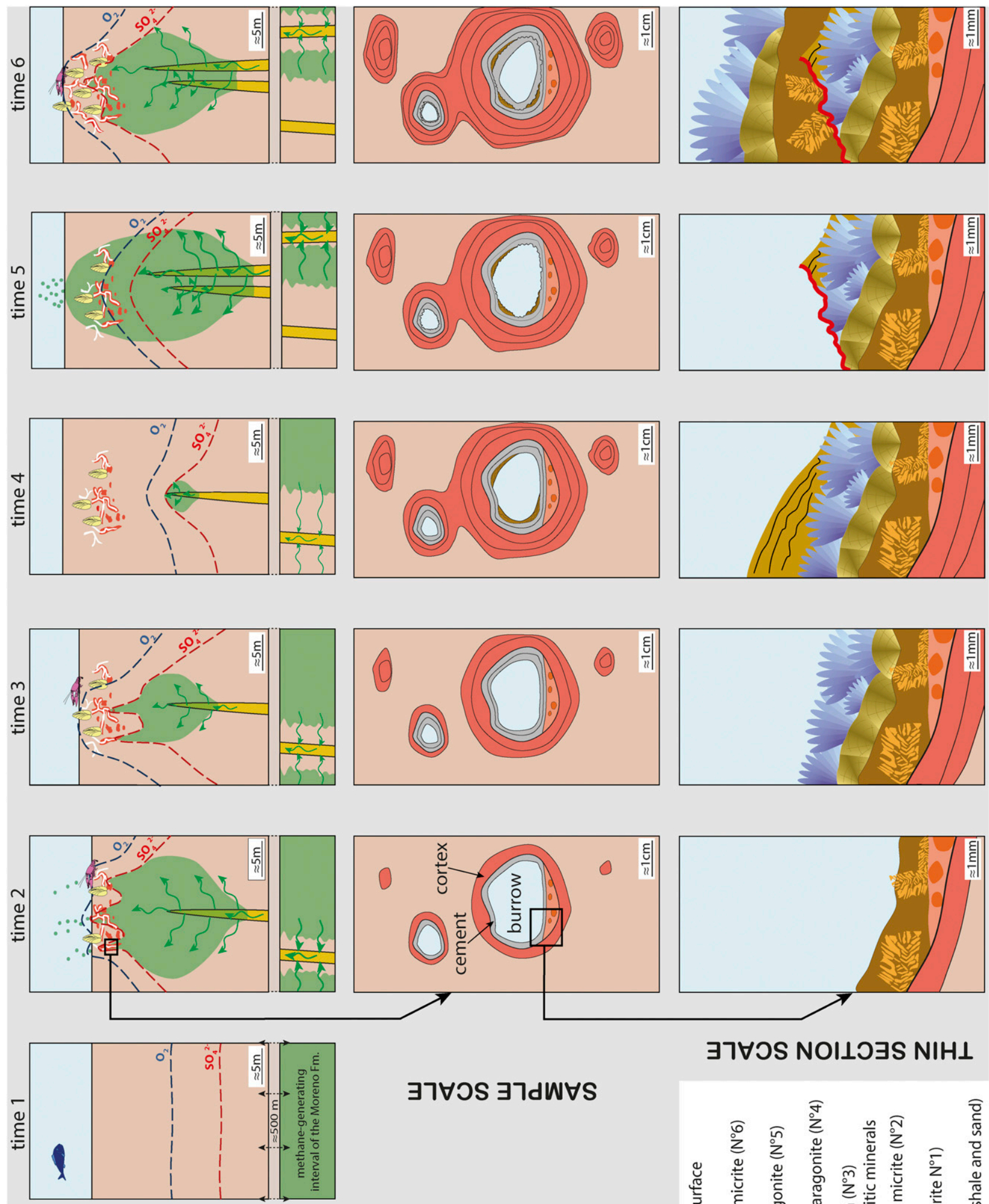

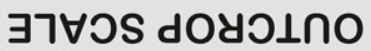

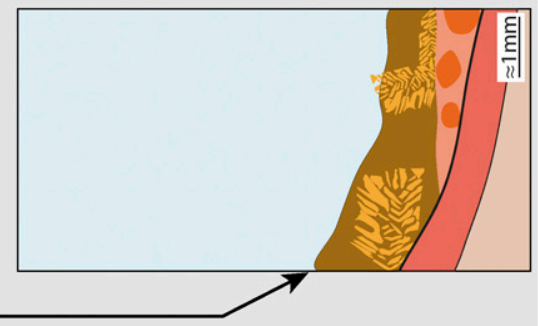

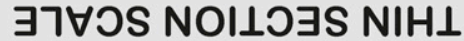

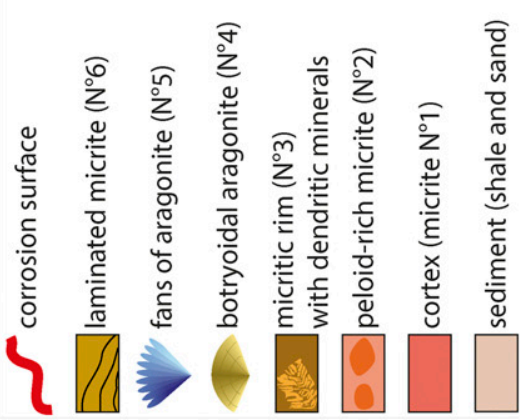




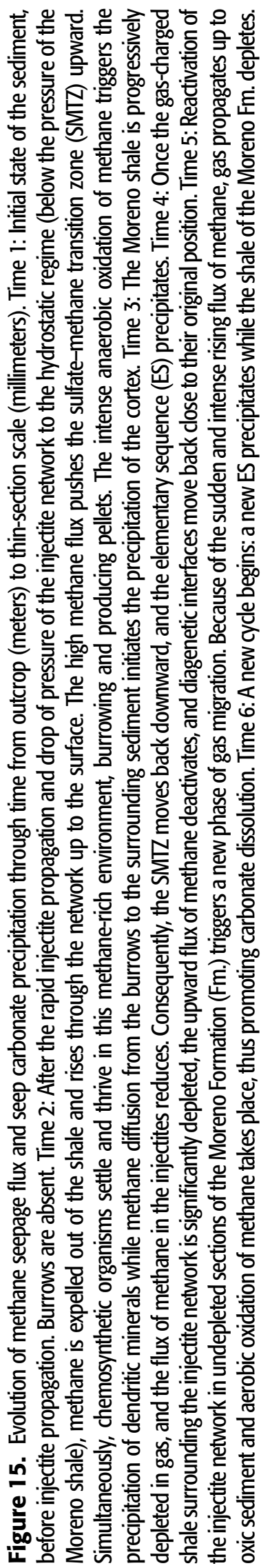

One key parameter that controls biogenic gas generation is temperature (Rice and Claypool, 1981): the optimum interval ranges from $30^{\circ} \mathrm{C}$ to $50^{\circ} \mathrm{C}$ $\left(86^{\circ} \mathrm{F}\right.$ to $\left.122^{\circ} \mathrm{F}\right)$, and sterilization occurs above $70^{\circ} \mathrm{C}$ to $80^{\circ} \mathrm{C}\left(158^{\circ} \mathrm{F}\right.$ to $\left.176^{\circ} \mathrm{F}\right)$ (Wilhelms et al., 2001; Clayton, 2010; Sandu and Bissada, 2012; Stolper et al., 2014; Haeseler et al., 2015).

Vigorito and Hurst (2010) determined that the decompacted depth of the base of the Moreno Formation was approximately $1000 \mathrm{~m}(0.6 \mathrm{mi})$ during deposition of the Cima Sandstone Lentil. Paleotemperature at this depth was a function of geothermal heat flux, sea-floor temperature, and the thermal conductivity of the Moreno Formation (see Goto and Matsubayashi, 2009, for the thermal conductivity of an uncompacted shale: the overall lithology of the Moreno Formation).

Dickinson and Seely (1979) indicated that the geodynamic and structural context of the Great Valley during the Cenozoic was similar to that of the modern forearc basin of the Aleutians (ridged forearc basins). The average geothermal heat flow measured in the Aleutian forearc basin ranges between 40 and $45 \mathrm{~mW} / \mathrm{m}^{2}$ (430 and $485 \mathrm{~mW} / \mathrm{ft}^{2}$ ) (Blackwell and Richards, 2004). Based on vitrinite reflectance data, He et al. (2014) independently estimated a flux of $48.5 \mathrm{~mW} / \mathrm{m}^{2}\left(522 \mathrm{~mW} / \mathrm{ft}^{2}\right)$ for the earliest Paleocene in the Vallecitos Syncline, less than $30 \mathrm{~km}$ (19 mi) south of our study area. It thus seems reasonable to assess a range of 40 to $48.5 \mathrm{~mW} / \mathrm{m}^{2}$ (430 to $522 \mathrm{~mW} / \mathrm{ft}^{2}$ ) for the geothermal flux in the study area during the Paleocene.

Based on foraminiferal analysis, Martin (1964) ascribed a shoreface environment to the Dos Palos Shale Member, just below the Cima Sandstone Lentil. Given that the Paleocene was a time of greenhouse climate (Quillévéré et al., 2008), we may assume that the sea-floor temperature lay between $12^{\circ} \mathrm{C}\left(T_{\min }\right)$ and $20^{\circ} \mathrm{C}\left(T_{\max }\right)\left(53^{\circ} \mathrm{F}\right.$ and $\left.68^{\circ} \mathrm{F}\right)$.

Paleotemperature in the sediment column was assessed from a calculation of heat diffusion using Fourier's Law. Taking into account paleotemperature error margins, a significant part of the organic-rich section of the Moreno Formation was in the optimum temperature range for biogenic gas generation (Figure 13).

Bac (1990) provided further indication that microorganisms are involved in methane production. The author reported the presence of biomarkers typical of Archaea in the Moreno Formation $\left(\mathrm{C}_{14}\right.$ 
to $\mathrm{C}_{30}$ saturated and unsaturated acyclic isoprenoid hydrocarbons) and attributed them to methanogens, the presence of other types of archaea being considered as unlikely in the given context. The lower part of the Moreno Formation is thus considered the most likely source of biogenic methane involved in the precipitation of the seep carbonates.

\section{Expulsion Mechanisms and Gas Migration Pathway}

The clear geometric association between seep carbonates and underlying dykes at both outcrops $\mathrm{A}$ and B (Figure 4) suggests that dykes acted as hydrocarbon migration pathways. This is in line with the hypothesis of Minisini and Schwartz (2007), who observed a good overall statistical correlation over the $20 \mathrm{~km}$ (12 mi) of outcrop between the abundance of dykes and that of seep carbonates.

We propose the following hypotheses for the mechanisms of expulsion and migration of methane (Figures 14, 15).

Vétel and Cartwright (2010) described the mechanism of depressurization of an injectite network after its emplacement as follows: from an initial pressure above the minimum stress $\left(\sigma_{\mathrm{min}}\right)$, the critical value necessary for maintaining an open fracture, pressure rapidly decreases by pervasive fluid infiltration into the pore space of the host sediment or by connection to another permeable sand body or to the surface. In outcrops A and B, the tips of the dykes reached a depth very close to the sea floor and may even have erupted locally as sand volcanoes (Vigorito et al., 2008). Thus, after the injectite's propagation, the pressure rapidly dropped and stabilized at the hydrostatic regime $\left(P_{\text {hydro }}\right)$ both in the injectite network and in the parent reservoir (Figure 14).

The pressure rise in the Panoche Formation above fracturing pressure verifies that the Moreno shale constituted an efficient seal. As a result, it is likely that the pore pressure in the Moreno Formation $\left(P_{\text {Moreno }}\right)$, at least above the overpressured reservoirs, showed a pressure ramp, progressively reaching the fracturing value of the Panoche Formation (Swarbrick et al., 2002). Gas generation within the shale also potentially contributed to a rise in pressure (Osborne and Swarbrick, 1997).

Therefore, after pressure in the injectites stabilized at the hydrostatic regime $\left(P_{\text {hydro }}\right)$, the pressure in the shale $\left(P_{\text {Moreno }}\right)$ exceeded the pressure in the injectites and pore fluids of the Moreno Formation, including gas, started migrating into the depressurized injectites. In a process analogous to what happens after artificial hydraulic fracturing (e.g., for hydrocarbon production purposes in "tight reservoirs" or gas shale), gas drainage efficiency was the highest at the beginning and then progressively decreased through time as the shale surrounding the injectites lost its overpressure while its permeability decreased because of compaction.

The seepage pattern deduced from the observation of each ES, with a very important initial gas seepage that progressively decreased over time, would be explained by this mechanism.

Vétel and Cartwright (2010) extensively documented crosscutting relationships of the injectites in the Panoche Hills and used their observations as evidence for multiple episodes of sand injection caused by explosions of distinct overpressured sand bodies.

Each reactivation and propagation of the injectite network would have triggered a new cycle of gas flow into the injectites, thus explaining the repetitive character of the ES. The overall decrease in intensity may have resulted from the progressive rarefaction of undrained, overpressured, domains in the lower Moreno Formation.

The 50-m (164-ft)-thick chemosynthetic fauna-rich area in outcrop B suggests that hydrocarbon seepage, although variable in intensity, lasted long enough for $50 \mathrm{~m}(164 \mathrm{ft})$ of siliciclastic sediment to be deposited.

\section{Ecology of Seep Fauna}

The distribution of the fauna in a seep environment is controlled by the local conditions created by fluid seepage (Levin, 2005).

The presence of chemosynthetic bivalves and tube worms in outcrop $B$ and their complete $a b-$ sence in outcrop A and the rest of the study area are related to the large number and close proximity of underlying dykes. The amount, regularity, and spatial extension of the methane supply were probably considerably higher in outcrop B than in A, allowing the establishment of chemosynthetic animals.

Unlike bivalves and tubeworms, Thalassinoides is present at both outcrops $A$ and $B$, in most mounds of the Panoche Hills that are not directly connected to 
dykes, but very rarely in curst and nodules. If Thalassinoides were widespread within the siliciclastic seabed sediment before its cementation by carbonate concretions, Thalassinoides should be found equally in all types of concretions. Consequently, the crustaceans creating the burrows probably sought the specific environment of the methane seeps, whose flux was higher around mounds than around nodules and crusts.

On sea-floor maps, Gay et al. (2006) noticed that mussels, clams, and tube worms were restricted to the central area of pockmarks with relatively high fluid flow, whereas burrows extended farther on the edge of the pockmarks. All known modern lucinids and Vestimentifera are chemosynthetic and strictly restricted to reduced environments (Kiel, 2010), whereas most crustaceans found in seeps are not endemics but opportunistic species that can take advantage of this environment, feeding directly or indirectly on chemosynthetic bacteria (Martin and Haney, 2005). This may explain the relative widespread distribution of the Thalassinoides in comparison with bivalves and tube worms.

In contrast with the scarce distribution of tube worms and mussels in outcrop B, these species are often regrouped in dense bush and pavement structures on modern sea-floor observations (Levin, 2005; Judd and Hovland, 2007) and in the fossil records (Campbell et al., 2008). Lucinids in association with tube worms have been reported (Hashimoto et al., 1995); however, little is known about the distribution of lucinids around seeps because of their endobentic habitat. Taylor and Glover (2010) suspect that they are overlooked by remotely operated vehicle surveys.

Fluids used Thalassinoides burrows as preferential migration paths (e.g., Wiese et al., 2015).
This process would thus favor crustaceans' access to hydrocarbons. A possible positive feedback could then be promoted. With more burrows present, the gas flow would become more focused, and more crustaceans would be attracted to this area, once again increasing gas flow focus. This may explain the observed local concentrations of burrows and the localized precipitation of mounds.

\section{CONCLUSION}

The combined studies of two outcrops of seep carbonates in the Panoche Hills together with 1-D basin modeling allow us to propose the following model for methane migration and associated seep carbonate precipitation: Sandstone dykes sourced from the Upper Cretaceous Panoche Formation were intruded into the overlying biogenic-methane-generating Maastrichtian to Danian Moreno Formation. Injectites eventually reached the seabed and released the overpressure of the sand injectite system. From this point on, gas migrated from the Moreno Formation into the injectite network and converged upward to the sea floor. This lead to precipitation of seep carbonates. Consistent paragenetic sequences of the seep carbonates record the progressive decrease of venting after the initial burst. This is attributed to the progressive gas depletion of the naturally fractured shale. Multiple reactivations of the injectite network ultimately led to the reactivation of methane seepage and repetition of the mineral paragenetic sequences. The outcrop of the Panoche Hills can thus be viewed as one of the first recognized examples of gas-shale production by hydraulic fracturing, approximately 60 m.y. before the technique was adopted by mankind for industrial purposes. 
APPENDIX: STABLE CARBON AND OXYGEN ISOTOPE VALUES FOR CARBONATES OF OUTCROPS A AND B

Table 2.

\begin{tabular}{|c|c|c|c|c|c|}
\hline Outcrop & $\begin{array}{c}\text { Sample } \\
\text { ID }\end{array}$ & $\begin{array}{c}\delta^{13} \mathrm{C} \\
(\% \mathrm{PDB})\end{array}$ & $\begin{array}{c}\delta^{18} \mathrm{O} \\
(\% \mathrm{PDB})\end{array}$ & Symbol & $\mathbf{N}^{\circ}$ \\
\hline B & KL014909 & -46.41 & 1.23 & $x$ & 1 \\
\hline B & KL014910 & -40.14 & 1.24 & $x$ & 1 \\
\hline B & KL014924 & -46.16 & 1.2 & $x$ & 1 \\
\hline B & KL014925 & -45.92 & 2.09 & $x$ & 1 \\
\hline B & KL014931 & -45.05 & 0.99 & $x$ & 1 \\
\hline A & KL014933 & -42.16 & 0.79 & $x$ & 1 \\
\hline A & KL014633 & -40.91 & 1.4 & $x$ & 1 \\
\hline A & KL014634 & -49.22 & 0.93 & $x$ & 1 \\
\hline A & KL014635 & -47.47 & 1.12 & $x$ & 1 \\
\hline A & KL014638 & -47.7 & 0.96 & $x$ & 1 \\
\hline A & KL014639 & -48.55 & 0.95 & $x$ & 1 \\
\hline A & KL014642 & -45.97 & 0.59 & $x$ & 1 \\
\hline A & KL014643 & -46.77 & 0.88 & $x$ & 1 \\
\hline A & KL014644 & -47.66 & 0.97 & $x$ & 1 \\
\hline A & KL014645 & -48.55 & 1.11 & $x$ & 1 \\
\hline A & KL014646 & -49.49 & 1.04 & $x$ & 1 \\
\hline A & KL014647 & -48.57 & 0.86 & $x$ & 1 \\
\hline A & KL014661 & -49.3 & 0.69 & $x$ & 1 \\
\hline A & KL014663 & -49.16 & 0.64 & $x$ & 1 \\
\hline A & KL014664 & -47.64 & 0.6 & $x$ & 1 \\
\hline A & KL014666 & -48.47 & 0.77 & $x$ & 1 \\
\hline A & KL014667 & -49.84 & 0.97 & $x$ & 1 \\
\hline A & KL014668 & -50.66 & 0.77 & $x$ & 1 \\
\hline A & KL014669 & -50.34 & 0.9 & $x$ & 1 \\
\hline A & KL014670 & -49.03 & 1.02 & $x$ & 1 \\
\hline A & KL014675 & -48.07 & 1.04 & $x$ & 1 \\
\hline A & KL014677 & -49.04 & 0.89 & $x$ & 1 \\
\hline A & KL014678 & -50.51 & 0.84 & $x$ & 1 \\
\hline A & KL014679 & -50.48 & 0.84 & $x$ & 1 \\
\hline A & KL014680 & -50.88 & 0.92 & $x$ & 1 \\
\hline A & KL014600 & -32.99 & 1.57 & $x$ & 1 \\
\hline A & KL014601 & -30.56 & 1.26 & $x$ & 1 \\
\hline B & KL015117 & -43.95 & 3.37 & $x$ & 1 \\
\hline B & KL014837 & -43.47 & 2.89 & $x$ & 1 \\
\hline A & KL014605 & -34.06 & 1.3 & $x$ & 1 \\
\hline A & KL014610 & -34.5 & 1.13 & $x$ & 1 \\
\hline A & KL014648 & -48.27 & 0.75 & 0 & 2 \\
\hline A & KL014652 & -50.94 & 1.34 & 0 & 2 \\
\hline B & KL014838 & -40.86 & 3.57 & 0 & 2 \\
\hline B & KL014841 & -47.56 & 5.75 & 0 & 2 \\
\hline B & KL014843 & -49.17 & 2.05 & 0 & 2 \\
\hline A & KL014649 & -43.44 & 0.7 & $\approx$ & 3 \\
\hline A & KL014650 & -40.29 & 0.85 & $\approx$ & 3 \\
\hline
\end{tabular}

(continued)
Table 2. Continued

\begin{tabular}{|c|c|c|c|c|c|}
\hline Outcrop & $\begin{array}{c}\text { Sample } \\
\text { ID }\end{array}$ & $\begin{array}{c}\delta^{13} \mathrm{C} \\
(\% \circ \mathrm{PDB})\end{array}$ & $\begin{array}{c}\delta^{18} 0 \\
(\% \circ P D B)\end{array}$ & Symbol & $\mathbf{N}^{\circ}$ \\
\hline B & KL014902 & -50.17 & 0.63 & & $3+4+5$ \\
\hline B & KL014943 & -38.15 & 0.27 & & $3+4+5$ \\
\hline B & KL014944 & -39.71 & 0.21 & & $3+4+5$ \\
\hline B & KL014947 & -41.84 & 0.26 & & $3+4+5$ \\
\hline A & KL014716 & -32.45 & 0.9 & & $3+4+5$ \\
\hline B & KL014903 & -38.15 & 0.77 & & 5 \\
\hline A & KL014658 & -45.77 & 0.71 & & 5 \\
\hline B & KL014946 & -21.11 & -2.06 & & 6 \\
\hline A & KL014659 & -18.49 & 1.14 & & 6 \\
\hline B & KL014907 & 1.77 & 0.99 & & 7 \\
\hline B & KL014911 & -3.34 & 0.86 & & 7 \\
\hline B & KL014929 & -3.68 & -0.04 & & 7 \\
\hline B & KL014932 & -17.76 & 0.3 & & 7 \\
\hline B & KL014945 & -1.4 & -0.52 & & 7 \\
\hline B & KL014951 & -0.48 & 0.5 & & 7 \\
\hline A & KL014630 & 1.99 & -0.27 & & 7 \\
\hline A & KL014637 & 1.8 & -0.06 & & 7 \\
\hline A & KL014654 & 1.65 & 0.01 & & 7 \\
\hline A & KL014655 & 1.54 & 0.01 & & 7 \\
\hline A & KL014660 & 3.64 & -0.19 & & 7 \\
\hline A & KL014676 & 1.87 & -0.22 & & 7 \\
\hline B & KL015121 & 2.47 & 0.74 & & 8 \\
\hline A & KL014656 & 1.33 & 0.06 & & 8 \\
\hline A & KL014586 & 1.53 & -0.06 & & 9 \\
\hline A & KL014588 & 1.49 & -0.04 & & 9 \\
\hline A & KL014615 & 2.54 & 0.09 & & 10 \\
\hline A & KL014616 & 1.12 & 0.09 & & 11 \\
\hline A & KL014617 & -0.14 & 0.02 & & 12 \\
\hline A & KL014619 & -5.68 & -5.59 & & 13 \\
\hline A & KL014620 & -4.99 & -4.88 & & 13 \\
\hline A & KL014626 & -7.65 & -2.19 & & 15 \\
\hline A & KL014622 & -6.14 & -4.41 & & 16 \\
\hline A & KL014623 & -5 & -5.55 & & 16 \\
\hline A & KL014624 & -5.28 & -5.92 & & 17 \\
\hline A & KL014625 & -5.21 & -6.06 & & 17 \\
\hline
\end{tabular}

\section{REFERENCES CITED}

Agirrezabala, L. M., 2009, Mid-Cretaceous hydrothermal vents and authigenic carbonates in a transform margin, Basque-Cantabrian Basin (western Pyrenees): A multidisciplinary study: Sedimentology, v. 56, p. 969-996, doi: 10.1111/j.1365-3091.2008.01013.x.

Aloisi, G., C. Pierre, J.-M. Rouchy, J.-P. Foucher, and J. Woodside, 2000, Methane-related authigenic carbonates of eastern Mediterranean Sea mud volcanoes and their possible relation to gas hydrate destabilisation: Earth and Planetary Science Letters, v. 184, p. 321-338, doi: 10.1016/S0012-821X(00)00322-8. 
Aloisi, G., K. Wallmann, S. M. Bollwerk, A. Derkachev, G. Bohrmann, and E. Suess, 2004, The effect of dissolved barium on biogeochemical processes at cold seeps: Geochimica et Cosmochimica Acta, v. 68, p. 1735-1748, doi: 10.1016/j.gca.2003.10.010.

Anderson, R., and R. W. Pack, 1915, Geology and oil resources of the west border of the San Joaquin Valley north of Coalinga, California: US Geological Survey Bulletin 603, 220 p., doi:10.1086/622554.

Arning, E. T., E. C. Gaucher, W. van Berk, and H.-M. Schulz, 2015, Hydrogeochemical models locating sulfatemethane transition zone in marine sediments overlying black shales: A new tool to locate biogenic methane?: Marine and Petroleum Geology, v. 59, p. 563-574, doi: 10.1016/j.marpetgeo.2014.10.004.

Atwater, T., and P. Molnar, 1973, Relative motion of the Pacific and North American plates deduced from sea-floor spreading in the Atlantic, Indian, and South Pacific Oceans, in R. L. Kovach and A. Nur, eds., Proceedings of the Conference on Tectonic Problems of the San Andreas Fault System: Stanford, California, Stanford University, p. 136-148.

Bac, M. G., 1990, Origin, stratigraphic variability, and significance of hydrocarbon biomarkers in the Moreno formation, San Joaquin Basin, California, Master's thesis, Stanford University, Stanford, California, 133 p.

Bailey, E. H., W. P. Irwin, and D. L. Jones, 1964, Franciscan and related rocks and their significance in the geology of western California: San Francisco, California, California Division of Mines and Geology Bulletin 183, 177 p.

Bartow, J. A., 1991, The Cenozoic evolution of the San Joaquin Valley, California: US Geological Survey Professional Paper 1501, 40 p.

Bartow, J. A., and T. H. Nilsen, 1990, Review of the Great Valley sequence, eastern Diablo Range and northern San Joaquin Valley, central California: US Geological Survey Report 90-226, p. 1-2.

Bathurst, R. G. C., ed., 1971, Carbonate sediments and their diagenesis: Amsterdam, Elsevier, Developments in Sedimentology 12, $658 \mathrm{p}$.

Bayon, G., C. Pierre, J. Etoubleau, M. Voisset, E. Cauquil, T. Marsset, N. Sultan, E. Le Drezen, and Y. Fouquet, 2007, Sr/Ca and Mg/Ca ratios in Niger Delta sediments: Implications for authigenic carbonate genesis in cold seep environments: Marine Geology, v. 241, p. 93-109, doi: 10.1016/j.margeo.2007.03.007.

Blackwell, D., and M. C. Richards, 2004, Geothermal map of North America: AAPG, scale 1:6,500,000, 1 sheet.

Boetius, A., K. Ravenschlag, C. J. Schubert, D. Rickert, F. Widdel, A. Gieseke, R. Amann, B. B. Jørgensen, U. Witte, and O. Pfannkuche, 2000, A marine microbial consortium apparently mediating anaerobic oxidation of methane: Nature, v. 407, p. 623-626, doi:10.1038 /35036572.

Boetius, A., and F. Wenzhöfer, 2013, Seafloor oxygen consumption fuelled by methane from cold seeps: Nature Geoscience, v. 6, p. 725-734, doi:10.1038/ngeo1926.
Burton, E. A., 1993, Controls on marine carbonate cement mineralogy: review and reassessment: Chemical Geology, v. 105, p. 163-179, doi:10.1016/0009-2541(93)90124-2.

Campbell, K. A., 2006, Hydrocarbon seep and hydrothermal vent paleoenvironments and paleontology: Past developments and future research directions: Palaeogeography, Palaeoclimatology, Palaeoecology, v. 232, p. 362-407, doi:10.1016/j.palaeo.2005.06.018.

Campbell, K. A., J. D. Farmer, and D. Des Marais, 2002, Ancient hydrocarbon seeps from the Mesozoic convergent margin of California: Carbonate geochemistry, fluids and palaeoenvironments: Geofluids, v. 2, p. 63-94, doi: 10.1046/j.1468-8123.2002.00022.x.

Campbell, K. A., D. A. Francis, M. Collins, M. R. Gregory, C. S. Nelson, J. Greinert, and P. Aharon, 2008, Hydrocarbon seep-carbonates of a Miocene forearc (East Coast Basin), North Island, New Zealand: Sedimentary Geology, v. 204, p. 83-105, doi:10.1016/j.sedgeo .2008.01.002.

Clayton, C., 1992, Source volumetrics of biogenic gas generation, in R. Vially, ed., Bacterial gas: Paris, Technip, p. 191-204.

Clayton, C., 2010, Incorporation of biogenic gas generation into petroleum system models: Geological Society, London, Modelling Sedimentary Basins and Their Petroleum Systems Conference, London, June 3-4, 2010, $28 \mathrm{p}$.

Cosgrove, J., 1997, Hydraulic fractures and their implications regarding the state of stress in a sedimentary sequence during burial, in S. Sengupta, ed., Evolution of geological structures in micro- to macro-scales: London, Chapman \& Hall, p. 11-25, doi:10.1007/978-94-011-5870-1_2.

De Yoreo, J. J., and P. G. Vekilov, 2003, Principles of crystal nucleation and growth: Reviews in Mineralogy and Geochemistry, v. 54, p. 57-93, doi:10.2113/0540057.

Dickinson, W., and D. Seely, 1979, Structure and stratigraphy of forearc regions: AAPG Bulletin, v. 63, no. 1, p. 2-31, doi:10.1306/clea55ad-16c9-1 1d7-8645000102c1865d.

Duranti, D., and A. Mazzini, 2005, Large-scale hydrocarbondriven sand injection in the Paleogene of the North Sea: Earth and Planetary Science Letters, v. 239, p. 327-335, doi:10.1016/j.eps1.2005.09.003.

Feng, D., and H. H. Roberts, 2011, Geochemical characteristics of the barite deposits at cold seeps from the northern Gulf of Mexico continental slope: Earth and Planetary Science Letters, v. 309, p. 89-99, doi:10 .1016/j.eps1.2011.06.017.

Fonseca-Rivera, C., 1997, Late Cretaceous-Early Tertiary paleoceanography and cyclic sedimentation along the California margin: Evidence from the Moreno Formation, Ph.D. thesis, Stanford University, Stanford, California, $449 \mathrm{p}$.

Gay, A., M. Lopez, H. Ondreas, J.-L. Charlou, G. Sermondadaz, and P. Cochonat, 2006, Seafloor facies related to upward methane flux within a Giant Pockmark of the Lower Congo Basin: Marine Geology, v. 226, p. 81-95, doi:10.1016/j.margeo.2005.09.011.

Goto, S., and O. Matsubayashi, 2009, Relations between the thermal properties and porosity of sediments in the 
eastern flank of the Juan de Fuca Ridge: Earth, Planets, and Space, v. 61, p. 863-870, doi:10.1186/BF03353197.

Graham, S., C. McCloy, M. Hitzman, R. Ward, and R. Turner, 1984, Basin evolution during change from convergent to transform continental margin in central California: AAPG Bulletin, v. 68 , no. 3, p. 233-249, doi:10.1306 /ad460a03-16f7-11d7-8645000102c1865d.

Greinert, J., S. M. Bollwerk, A. Derkachev, G. Bohrmann, and E. Suess, 2002, Massive barite deposits and carbonate mineralization in the Derugin Basin, Sea of Okhotsk: Precipitation processes at cold seep sites: Earth and Planetary Science Letters, v. 203, p. 165-180, doi:10 .1016/S0012-821X(02)00830-0.

Haeseler, F., D. Levache, and B. Lamirand, 2015, Reservoir filling paths revealed by kinetic modeling of biodegradation at basin scale: International Petroleum Technology Conference, Doha, Qatar, December 6-9, 2015, 8 p., doi:10.2523/IPTC-18402-MS.

Hashimoto, J., K. Fujikura, Y. Fujiwara, M. Tanishima, S. Ohta, S. Kojima, and S. M. Yieh, 1995, Observations of a deep-sea biological community co-dominated by lucinid bivalve, Lucinoma spectabilis (Yokoyama, 1920) and vestimentiferans at the Kanesu-no-Se bank, Enshu-Nada, central Japan: Japan Agency for Marine-Earth Science and Technology Journal of Deep Sea Research, v. 11, p. 211-217.

He, M., S. Graham, A. H. Scheirer, and K. E. Peters, 2014, A basin modeling and organic geochemistry study in the Vallecitos syncline, San Joaquin Basin, California: Marine and Petroleum Geology, v. 49, p. 15-34, doi:10.1016/j .marpetgeo.2013.09.001.

Ho, S., D. Carruthers, and P. Imbert, 2016, Insights into the permeability of polygonal faults from their intersection geometries with Linear Chimneys: A case study from the Lower Congo Basin: Carnets de Géologie, v. 16, no. 2, p. 17-26, doi:10.4267/2042/58718.

Ho, S., J. A. Cartwright, and P. Imbert, 2012, Vertical evolution of fluid venting structures in relation to gas flux, in the Neogene-Quaternary of the Lower Congo Basin, Offshore Angola: Marine Geology, v. 332-334, p. 40-55, doi:10.1016/j.margeo.2012.08.011.

Hovland, M., M. Talbot, S. Olaussen, and L. Aasberg, 1985. Recently formed methane-derived carbonates from the North Sea floor, in B. M. Thomas, ed., Petroleum geochemistry in exploration of the Norwegian shelf: Salisbury, United Kingdom, Graham \& Trotman for the Norwegian Petroleum Society, p. 263-266, doi:10.1007 /978-94-009-4199-1_22.

Hurst, A., and J. A. Cartwright, eds., 2007, Sand injectites: Implications for hydrocarbon exploration and production: AAPG Memoir 87, 274 p.

Hurst, A., A. Scott, and M. Vigorito, 2011, Physical characteristics of sand injectites: Earth-Science Reviews, v. 106, p. 215-246, doi:10.1016/j.earscirev.2011.02.004.

Ingersoll, R. V., 1979, Evolution of the Late Cretaceous forearc basin, northern and central California: Geological Society of America Bulletin, v. 90, p. 813-826, doi:10.1130/0016-7606(1979)90<813:EOTLCF $>2.0$ $\mathrm{CO} ; 2$.
Ingersoll, R. V., 2008, Subduction-related sedimentary basins of the USA Cordillera, in A. D. Miall, ed., The sedimentary basins of the United States and Canada: Sedimentary Basins of the World 5, p. 395-428, doi:10.1016 /S1874-5997(08)00011-7.

Jonk, R., J. Parnell, and A. Hurst, 2005, Aqueous and petroleum fluid flow associated with sand injectites: Basin Research, v. 17, p. 241-257, doi:10.1111/j.1365-2117 2005.00262.x.

Judd, A., and M. Hovland, 2007, Seabed fluid flow: The impact on geology, biology and the marine environment: Cambridge, United Kingdom, Cambridge University Press, 492 p., doi:10.1017/CBO9780511535918.

Kiel, S., ed., 2010, The vent and seep biota: Aspects from microbes to ecosystems: Topics in Geobiology 33, 490 p., doi:10.1007/978-90-481-9572-5.

Kiel, S., 2013, Lucinid bivalves from ancient methane seeps: Journal of Molluscan Studies, v. 79, p. 346-363, doi: 10.1093/mollus/eyt035.

Levin, L., 2005, Ecology of cold seep sediments: Interactions of fauna with flow, chemistry and microbes, in R. N. Gibson, R. J. A. Atkinsonad, and J. D. M. Gordon, eds, Oceanography and Marine Biology—An Annual Review, v. 43: Boca Raton, Florida, CRC Press, p. 1-46.

Magoon, L. B, and W. G. Dow, eds., 1994, The petroleum system-From source to trap: AAPG Memoir 60, 665 p.

Marlow, J., J. Peckmann, and V. Orphan, 2015, Autoendoliths: A distinct type of rock-hosted microbial life: Geobiology, v. 13, p. 303-307, doi:10.1111/gbi.12131.

Martin, L., 1964, Upper Cretaceous and Lower Tertiary foraminifera from Fresno County, California: Vienna, Austria, Geologische Bundesanstalt, 128 p., 10.2307/1484100.

Martin, J. W., and T. A. Haney, 2005, Decapod crustaceans from hydrothermal vents and cold seeps: A review through 2005: Zoological Journal of the Linnean Society, v. 145, p. 445-522, doi:10.1111/j.1096-3642.2005.00178.x.

Mazzini, A., R. Jonk, D. Duranti, J. Parnell, B. Cronin, and A. Hurst, 2003, Fluid escape from reservoirs: Implications from cold seeps, fractures and injected sands Part I. The fluid flow system: Journal of Geochemical Exploration, v. 78-79, p. 293-296, doi:10.1016/S0375-6742(03) 00046-3.

McGuire, D. J., 1988, Stratigraphy, depositional history, and hydrocarbon source-rock potential of the Upper Cretaceous-Lower Tertiary Moreno Formation, central San Joaquin basin, California, Ph.D. thesis, Stanford University, Stanford, California, $231 \mathrm{p}$.

Minisini, D., and H. Schwartz, 2007, An early Paleocene cold seep system in the Panoche and Tumey Hills, central California (United States), in A. Hurst and J. Cartwright, eds., Sand injectites: Implication for hydrocarbon production: AAPG Memoir 87, p. 185-197.

Naudts, L., J. Greinert, J. Poort, J. Belza, E. Vangampelaere, D. Boone, P. Linke, J.-P. Henriet, and M. De Batist, 2010, Active venting sites on the gas-hydrate-bearing Hikurangi Margin, off New Zealand: Diffusive- versus bubblereleased methane: Marine Geology, v. 272, p. 233-250, doi:10.1016/j.margeo.2009.08.002. 
Norris, R. M., and R. W. Webb, 1990, Geology of California: New York, John Wiley \& Sons, 571 p.

Osborne, M. J., and R. E. Swarbrick, 1997, Mechanisms for generating overpressure in sedimentary basins: A reevaluation: AAPG Bulletin, v. 81, no. 6, p. 1023-1041, doi: 10.1306/8626D36F-173B-11D7-8645000102C1865D.

Paull, C., B. Hecker, R. Commeau, R. Freeman-Lynde, C. Neumann, W. Corso, S. Golubic, J. Hook, E. Sikes, and J. Curray, 1984, Biological communities at the Florida Escarpment resemble hydrothermal vent taxa: Science, v. 226, p. 965-967, doi:10.1126/science.226.4677.965.

Paull, C. K., and W. Ussler III, 2008, Re-evaluating the significance of the seafloor accumulations of methanederived carbonates: Seepage or erosion indicators?: 6th International Conference on Gas Hydrates, Vancouver, Canada, July 6-20, 2008, p. 1-12, doi:10.14288 $/ 1.0041014$.

Payne, M. B., 1951, Type Moreno Formation and overlying Eocene strata on the west side of the San Joaquin Valley, Fresno and Merced counties: San Francisco, State of California Department of Natural Resources, Division of Mines, $29 \mathrm{p}$.

Peckmann, J., and V. Thiel, 2004, Carbon cycling at ancient methane-seeps: Chemical Geology, v. 205, p. 443-467, doi:10.1016/j.chemgeo.2003.12.025.

Peters, K. E., L. B. Magoon, Z. C. Valin, and P. G. Lillis, 2007, Source-rock geochemistry of the San Joaquin Basin Province, California, in A. H. Scheirer, ed., Petroleum systems and geologic assessment of oil and gas in the San Joaquin Basin Province, California: US Geological Survey Professional Paper 1713, p. 1-102, doi:10.3133/pp1713.chl1.

Presser, T. S., and W. C. Swain, 1990, Geochemical evidence for Se mobilization by the weathering of pyritic shale, San Joaquin Valley, California, U.S.A: Applied Geochemistry, v. 5, p. 703-717, doi:10.1016/0883-2927(90) 90066-E.

Quillévéré, F., R. D. Norris, D. Kroon, and P. A. Wilson, 2008, Transient ocean warming and shifts in carbon reservoirs during the early Danian: Earth and Planetary Science Letters, v. 265, p. 600-615, doi:10.1016/j .eps1.2007.10.040.

Reeburgh, W. S., 2007, Oceanic methane biogeochemistry: Chemical Reviews, v. 107, p. 486-513, doi:10.1021 /cr050362v.

Regnier, P., A. W. Dale, S. Arndt, D. LaRowe, J. Mogollón, and P. Van Cappellen, 2011, Quantitative analysis of anaerobic oxidation of methane (AOM) in marine sediments: A modeling perspective: Earth-Science Reviews, v. 106, p. 105-130, doi:10.1016/j.earscirev.2011.01.002.

Reitner, J., J. Peckmann, M. Blumenberg, W. Michaelis, A. Reimer, and V. Thiel, 2005, Concretionary methaneseep carbonates and associated microbial communities in Black Sea sediments: Palaeogeography, Palaeoclimatology, Palaeoecology, v. 227, p. 18-30, doi:10.1016/j.palaeo .2005.04.033.

Rice, D. D., and G. E. Claypool, 1981, Generation, accumulation, and resource potential of biogenic gas: AAPG Bulletin, v. 65 , no. 1, p. 5-25.
Riding, R., 2000, Microbial carbonates: The geological record of calcified bacterial-algal mats and biofilms: Sedimentology, v. 47, p. 179-214, doi:10.1046/j.1365-3091.2000.00003.x.

Ritger, S., B. Carson, and E. Suess, 1987, Methane-derived authigenic carbonates formed by subduction-induced pore-water expulsion along the Oregon/Washington margin: Geological Society of America Bulletin, v. 98, no. 2, p. 147-156, doi:10.1130/0016-7606(1987)98<147: MACFBS $>2.0 . C O ; 2$.

Roberts, H. H., 2001, Fluid and gas expulsion on the northern Gulf of Mexico continental slope: Mud-prone to mineralprone responses, in C. K. Paull and W. P. Dillon, eds., Natural gas hydrates: Occurrence, distribution, and detection: AGU Geophysical Monograph 124, p. 145-161, doi:10.1029/GM124p0145.

Sandu, C., and A. Bissada, 2012, Thermal modeling of microbial methane generation constrained by laboratory experiments: AAPG Search and Discovery article 41053, accessed January 15, 2016, http://www.searchand discovery.com/pdfz/documents/2012/41053sandu /ndx_sandu.pdf.html.

Schwartz, H., J. Sample, K. D. Weberling, D. Minisini, and J. C. Moore, 2003, An ancient linked fluid migration system: Cold-seep deposits and sandstone intrusions in the Panoche Hills, California, USA: Geo-Marine Letters, v. 23, p. 340-350, doi:10.1007/s00367-003-0142-1.

Scott, A., A. Hurst, and M. Vigorito, 2013, Outcrop-based reservoir characterization of a kilometer-scale sandinjectite complex: AAPG Bulletin, v. 97, no. 2, p. 309343, doi:10.1306/05141211184.

Stolper, D., M. Lawson, C. Davis, A. Ferreira, E. S. Neto, G. Ellis, M. Lewan, A. Martini, Y. Tang, and M. Schoell, 2014, Formation temperatures of thermogenic and biogenic methane: Science, v. 344, p. 1500-1503, doi: 10.1126/science.1254509.

Stroobants, N., F. Dehairs, L. Goeyens, N. Vanderheijden, and R. Van Grieken, 1991, Barite formation in the Southern Ocean water column: Marine Chemistry, v. 35, p. 411421, doi:10.1016/S0304-4203(09)90033-0.

Swarbrick, R. E., M. J. Osborne, and G. S. Yardley, 2002, Comparison of overpressure magnitude resulting from the main generating mechanisms, in A. R. Huffman and G. L. Bowers, eds., Pressure regimes in sedimentary basins and their prediction: AAPG Memoir 76, p. 1-12.

Taylor, D., and E. A. Glover, 2010, Chemosymbiotic bivalves, in S. Kiel, ed., The vent and seep biota: Aspects from microbes to ecosystems: Topics in Geobiology 33, p. 107-135, doi:10.1007/978-90-481-9572-5_5.

Torres, M. E., G. Bohrmann, T. E. Dubé, and F. G. Poole, 2003, Formation of modern and Paleozoic stratiform barite at cold methane seeps on continental margins: Geology, v. 31, p. 897-900, doi:10.1130/G19652.1.

US Geological Survey, 1956, Geologic map of the Chounet Ranch quadrangle, Fresno County, California (revised 1971): 7.5 Minute Series (Topographic), scale 1:24,000, 1 sheet, accessed November 17, 2016, https://prd-tnm .s3.amazonaws.com/StagedProducts/Maps/HistoricalTopo /2/13256/4763906.pdf. 
Vétel, W., and J. Cartwright, 2010, Emplacement mechanics of sandstone intrusions: Insights from the Panoche Giant Injection Complex, California: Basin Research, v. 22, p. 783-807, doi:10.1111/j.1365-2117.2009.00439.x.

Vigorito, M., and A. Hurst, 2010, Regional sand injectite architecture as a record of pore- pressure evolution and sand redistribution in the shallow crust: Insights from the Panoche Giant Injection Complex, California: Journal of the Geological Society, v. 167, p. 889-904, doi:10.1144 /0016-76492010-004.

Vigorito, M., A. Hurst, J. Cartwright, and A. Scott, 2008, Regional-scale subsurface sand remobilization: Geometry and architecture: Journal of the Geological Society, v. 165, p. 609-612, doi:10.1144/0016-76492007-096.
Weberling, K. D., 2002, Clastic intrusion and cold seeps in the Late Cretaceous-early Tertiary Great Valley forearc basin, Panoche Hills, CA: Structural context of a linked fluid system, Master's thesis, University of California, Santa Cruz, California, $48 \mathrm{p}$.

Wiese, F., S. Kiel, A. Pack, E. O. Walliser, and L. M. Agirrezabala, 2015, The beast burrowed, the fluid followed-Crustacean burrows as methane conduits: Marine and Petroleum Geology, v. 66, no. 3, p. 631-640, doi:10.1016/j. marpetgeo.2015.03.004.

Wilhelms, A., S. R. Larter, I. Head, P. Farrimond, R. di-Primio, and C. Zwach, 2001, Biodegradation of oil in uplifted basins prevented by deep-burial sterilization: Nature, v. 411, p. 1034-1037, doi:10.1038/35082535. 